\title{
Oudolla tavalla eksyksissä
}

\author{
Uskomusperinne, kulttuuriset merkitykset ja selittävä tiedonintressi
}

\author{
Pasi Enges ja Kaarina Koski
}

\begin{abstract}
Metsä vaikenee. Linnut eivät enää viheltele suloisen surumielisiä nuottejaan ja koko päivän jatkunut tuulen havistus on pudonnut lehdiltä. Ikään kuin metsä olisi kääntynyt sisäänpäin, heittäytynyt nurjamieliseksi. Kulkija kokee sen itsessäänkin. On kuin metsä olisi jotenkin häneen tyytymätön. Paikkoja ei oikein hahmota, vaikka metsä on tuttu ja siellä on kuljettu vaikka kuinka usein. Polkuja ei löydy ja jos löytyykin, ei niillä tunnu olevan luotettavaa johdatusvoimaa, vaan ne päättyvät umpimättäisiin. Isot sammalpeitteiset kivet tuntuvat asettuvan tahallaan tielle. Kulkija tajuaa olevansa eksyksissä, vaikka järki vakuuttaa muuta. Hänen mielessään pilkistelevät vuoronperää panikoituminen ja sen rinnalle jostain noussut huumaantuminen, joka ei ole luonteeltaan miellyttävää. Tietämättä miten tilanteeseen suhtautua hän jähmettyy, käy tunnottomaksi, ei saa jalkaa toisen eteen. Siinä hän on - ja metsä tulee päälle kuin liikkuva varjo. Kuluu tuokio - vai pettääkö ajantajukin? - kunnes maisema saa taas tutut kasvot. Niin tietysti, tässähän sitä ollaan. Tuo polku vie tielle, tuossa männyssä on se pöllönpönttö. Kohta pilkottaa kotitalokin. Olo ei silti pitkään tasaannu, sillä kulkija on yhdestä asiasta varma: se ei ollut tavallista eksymistä, vaan jotain muuta. (Leppänen 2012.)
\end{abstract}

\section{Johdanto}

Kokemus eksymisestä, yksilön ainakin hetkellinen epätietoisuus omasta fyysisestä sijainnista tai oikeasta kulkusuunnasta, on hyvin yleinen - ellei yleisinhimillinen. Tavallinen eksyminen voi johtua ympäristön outoudesta tai eksyjän kokemattomuudesta ja taitojen puutteesta. Tilanne ratkeaa eksyneen omin ponnistuksin tai muiden ihmisten avulla, ja vaikka kokemus voi olla mieleenpainuva ja pelottavakin, se liitetään arkikokemuksen piiriin. Eksyminen voi olla myös epätavallista ja arkikokemuksesta selvästi poikkeavaa. Vanhassa kansanuskossa ja murteissa on ollut erityissanastoa, kuten metsänpeitto ja hiidenkätkö, joilla on tarkoitettu tietyn tyyppistä kadoksiin joutumista. Nykysuomen yleiskielessä ei kuitenkaan ole yleistermiä tällaiselle erityiseksi ja oudoksi tunnistettavalle eksymiselle. Englannin kielessä eron voi tehdä sanaparilla to go astray, joka tarkoittaa tavallista eksymistä, ja to be spirited away, joka viittaa epätavalliseen eksymiseen. To spirit away on idiomi, joka merkitsee jonkun tai jonkin kuljettamista pois salaa tai hämäräperäisesti (ks. The Free Dictionary; Etymonline). ${ }^{1}$ Eksymiseen sovitettuna ilmaus siirtää kokijan subjektista objektiksi ja on kuvaava: se tarkoittaa salaperäistä, usein tutussakin ympäristössä tapahtuvaa eksymistä ei-inhimilliseksi ymmärretyn toimijan vaikutuksesta sekä eksyneen kokemusta oman psykofyysisen tilansa

1 Ilmauksen sisältämä viittaus henkiin (spirit) on arkipuheessa metaforinen, mutta mielikuva olennoista toimijoina tulee esille uskomusperinteessä tai fantasiassa. Tunnetuin esimerkki asiaan liittyvästä fantasiasta on Hayao Miyazakin elokuva Henkien kätkemä vuodelta 2001 (IMDB, Spirited Away). 
tai ympäröivän todellisuuden muuttumisesta. Ihminen ei ole itse eksynyt, vaan eksytetty, ja ulkopuolisen vaikutuksen objektina hänen omat mahdollisuutensa vaikuttaa tilanteeseen voivat olla vähäiset tai jopa olemattomat. (Wikman 1961,11.)

Kokemukset yliluonnolliseksi käsitetystä eksymisestä ovat kansainvälisiä ja niiden tulkinnat noudattavat kussakin kulttuurisessa kontekstissa ajankohtaisiksi ja sopiviksi koettuja malleja (esim. Mencej 2018). Käsittelemme tässä artikkelissa kertomuksia eksymisistä, joita niistä kertoneet ovat pitäneet arkikokemuksesta poikkeavina, outoina ja erityisinä, sekä erityisesti metsänpeiton käsitettä. Tarkastelemme tieteellisten diskurssien ja nykypäivän verkkokeskustelujen suosimia selityksiä epätavallisille eksymiskokemuksille ja sitä, millaisiin todellisuuskuviin ja ihanteisiin ne perustuvat. Taustaksi esittelemme vanhan uskomusperinteen eksymiskuvastoja, joihin sekä tieteelliset tulkinnat että verkkokeskustelut usein viittaavat. Tarkastelussa ovat myös tutkijoiden tiedonintressit ja niitä ohjaavat arvot.

Määräävin jako eksymiselle eri aikoina annettujen selitysten sisällössä kulkee yliluonnollisen $^{2}$ ja naturalistisen katsantokannan välillä. Naturalistiset selitykset etsivät orientaation katoamisen syytä konkreettisista olosuhteista tai kokijasta itsestään. Ne voivat perustua arkirealismiin tai olla tiedepohjaisia ja nojautua esimerkiksi fysiologiaan ja psykologiaan. Yliluonnollisessa kehyksessä sen sijaan eksyminen koetaan arkitodellisuuteen kuulumattomien olentojen tai voimien aiheuttamaksi. Nykyään sen taustalla ovat yleensä kristilliset tai esoteeriset diskurssit. 1800-1900-luvuilla tallennetuissa aineistoissa - tarinoissa, memoraateissa, yleistävissä uskomusväittämissä ja riittikuvauksissa - tulkintakehyksenä ovat tuon ajan paikalliset näkemykset ihmisen elinpiiriä ympäröivästä näkymättömästä todellisuudesta, sen asukkaista ja niiden kohtaamisesta. Jotta yliluonnollisia olentoja on voitu toistuvasti esittää selityksenä eksymiselle, ne on täytynyt ymmärtää ja hyväksyä todella olemassa oleviksi ja ihmisten elämään vaikuttaviksi (Simonsuuri 2006, 13-17). Kaikki eivät kuitenkaan ole jakaneet yksimielisesti uskomuspohjaisia tulkintoja. 1800-luvun Suomessa merkittäviä olivat myös kirkon, koululaitoksen ja sanomalehtien tarjoamat todellisuuskuvat, ja uskomuksia haastettiin myös arkijärjen nojalla. (Koski 2011, 84-85; Stark 2006, 39.) Vanhassa uskomusaineistossa kuuluu silti vain harvoin modernin maailman ääni. Folkloren keruu miellettiin vielä 1900-luvun alkupuolella menneisyyden tallentamiseksi, ja kansaan kohdistuva hierarkkinen katse määritteli kertojat oppimattomiksi ja taikauskoisiksi (Koski 2011, 30-32; Kurki 2002, 52-57; Peltonen 2004, 205-207). Keruuta ja tutkimusta ohjanneiden uskomuspainottuneiden intressien vuoksi kansanomainen skeptisyys osana uskomusperinnettä on jäänyt myös tutkimuksessa vähäiselle huomiolle (Roper 2018, 225-229, 233-234). Suomalaisessa uskomustarinoiden luokituksessa on oma tyyppinumeronsa tarinoille, jotka esittävät uskomusilmiöille luonnollisen selityksen (tarinatyyppi B $501^{3}$ ), mutta niitä on myös pidetty modernina ilmiönä ja uskomusperinteen degeneraationa (Simonsuuri 2006, 17). määrittelemien kriteerien pohjalta ottamatta huomioon tutkittavien omia jäsennyksiä (esim. Honkasalo 2017, 30-41; Koski ja Honkasalo 2015). Monissa tapauksissa termi kuitenkin kuvaa tutkittavienkin näkemystä asiasta. Aiheeseen liittyvästä terminologiasta ja käsitteen käyttökelpoisuuden perusteluista ks. esim. Enges 2012, 63-64; Rancken 2017, 54-61.

3 Tarinatyyppinumerot viittaavat uskomustarinoiden tyyppi- ja motiiviluetteloon (Jauhiainen 1999), jonka mukaisesti Suomalaisen Kirjallisuuden Seuran arkiston perinteen ja nykykulttuurin kokoelmien uskomustarina-kortisto on järjestetty. Perinnealueluokituksineen ja tyyppi- ja motiivikohtaisine lukumäärätietoineen luettelo on myös käyttökelpoinen, joskin karkeasti yleistävä "oikotie" suomalaisen, karjalaisen ja saamelaisen uskomustarinaston sisältöihin ja teemoihin. (Ks. Jauhiainen 1999, 11-15, 19-25, 27-44.) 
Yliluonnollisen käsittelyä humoristisissa perinnelajeissa kuten kaskuissa ja pilasaduissa ei myöskään yleensä ole tarkasteltu tutkimuksessa epäuskon kannalta. ${ }^{4}$

Eksymisen kohdalla arkistoon on tallennettu yliluonnolliseksi koetun eksymisen kuvauksia, ja mahdolliset niitä kiistävät selitykset ovat jääneet keruun ulkopuolelle. Jälkikäteen on vaikea arvioida, millaista neuvottelu eksymisen luonteesta on ollut tai millainen rooli kansanomaisella epäuskolla on ollut ennen modernisaation vaikutusta. Viimeistään 1900-luvun aikana kansanomaiset tulkinnat saavat yhä enemmän vaikutteita oppineista ja tieteellisistä diskursseista kuten lääketieteellisestä yliluonnollisten kokemusten selittämisestä neurologisilla häiriöillä (ks. Valk 2015, 143).

Lähdemme seuraavassa liikkeelle taustoittamalla aihetta vanhemman uskomusperinteen eksyttäjäkuvilla ja -selityksillä. Sitten käsittelemme poikkeuksellisten kokemusten tieteellisiä selityksiä ja tarkastelemme lähimenneisyyden ja nykypäivän eksymiskokemuksia kirjoitus-ja internet-aineistojen valossa sekä hahmottelemme eksymiselle annettuja uudenlaisia merkityksiä. Tavoitteena on osoittaa, miten eksymiselle annetut selitykset ovat sidoksissa aikaansa sekä kulttuuriin ja arvoihin. Itse eksymiskokemuksia kertomusaineistot eivät tavoita luotettavasti, mutta uusissa ja vanhoissa kuvauksissa näkyy sekä variaatiota että huomattavaa samankaltaisuutta sensorisine ja emotionaalisine peruspiirteineen.

\section{Vanhan uskomusperinteen tulkintakehys}

Suomalaisiin arkistoihin kuten Suomalaisen Kirjallisuuden Seuran arkistoon (SKS) sekä Kotimaisten kielten keskukseen (KOTUS) kertyneessä suomalaisessa, karjalaisessa ja saamelaisessa aineistossa esiintyy käsityksiä useista olennoista tai voimista, joiden kohtaamisesta tai toimista epätavallisen eksymisen on katsottu johtuvan. ${ }^{5}$ Verrattuna muuhun Eurooppaan, missä eksyminen on uskomusperinteessä selitetty yleensä noitien taikka haltija- ja vainajaolentojen toiminnalla, tälle alueelle omaleimainen on ympäristön kuten metsän itsensä aiheuttama eksyttäminen (Mencej 2018, 60-62). Eksyttäjäksi on siis ymmärretty hahmoltaan epämääräinen ja persoonaton entiteetti, kuten metsä, vuori tai järvi, joka "ottaa", "nielee" tai "piilottaa" ihmisen. Tällaisen eksymisen tunnetuin ja laajalle levinnyt ilmenemismuoto on metsänpeitto (tarinatyypit K 201-300). Käytännössä metsänpeittoon johdattajan persoonattomuuden ja persoonallisuuden raja on kuitenkin liukuva, sillä yhtä hyvin kuin itse metsä, kertomuksissa eksyttäjäksi voidaan nimetä jokin metsän olento, tai tapaus voidaan esittää noituudella aiheutetuksi (Sarmela 2007, 344-345; Tarkka 2005, 292-295). Tavassa joutua eksyksiin ja erityisesti olentojen kohdalla esiintyy alueellista variaatiota.

Eksymiseksi voidaan lukea tarinoissa pitempiaikainen kadoksiin joutuminen taikka vain hetkellinen ajan- ja paikantajun tai toimintakyvyn katoaminen, joka luo kokemuksen muuttuneesta todellisuudesta tai fyysisen ja psyykkisen tilan muutoksesta. Toimintakyvyn muutos liittyy erityisesti hiidenväen tai äpärän kohtaamiseen. Vainajaolentoihin kuuluvasta hiidenväestä on kerrottu suhteellisen tarkasti rajatulla alueella Pohjois-Satakunnassa. Se kulkee

Esimerkiksi Ulrika Wolf-Knuts on tulkinnut humoristista kerrontaa pirusta osana kokonaiskuvaa ja yhtenä kansanomaisena tapana lähestyä pelottavaa ja arkaluontoista aihetta (Wolf-Knuts 1991, 91-92, 113-117). Annikki Kaivola-Bregenhøj on katsonut kaskuna toteutuneen uskomustarinan kertovan siitä, että sosiaalinen kommentaari on ollut kertojalle yliluonnollista sisältöä tärkeämpi. Hän toteaa kuitenkin kertojan naurahtelun osoittaneen, ettei tämä suhtautunut uskomussisältöön vakavasti. (Kaivola-Bregenhøj 1988, 201.)

5 Eksyttävät olennot esitellään tässä tausta-aineistona vain karkeasti tyyppinumeroittain aiemman tutkimuksen pohjalta ilman primaariaineiston analyysia. 
helinän tai surinan saattelemana suurina joukkoina pitkin omia, ihmissilmälle näkymättömiä polkujaan. Niiden tielle osuva eksyy, tai hiidenväki hilvaa tai hilvasee. Hilvattu menee hetkellisesti tiedottomaksi tai päästään sekaisin taikka menettää liikuntakykynsä. Lumouksen voi rikkoa taikuudella kuten riisuutumalla ja pukemalla uudelleen kaikki vaatteet nurin päin. On myös kerrottu, että hiidenväki ei häiritse nukkuvaa, joten nukkumisen teeskenteleminen on tehokas suojautumiskeino hiidenväeltä. (Tarinatyyppi C 1781; Koski 2011, 149-151; SMS 2012, s.v. hilvata.)

Pohjois-Suomessa sekä suomalaisessa että saamelaisessa perinteessä inminen voi menettää ajan- ja paikantajunsa pelästyttyään äpärä-lapsivainajaa (pohjoissaameksi eahpáraš) (tarinatyyppi C 1051). Olennon yllättävä kohtaaminen voi aiheuttaa raimautumisen (raimmahallan), joka on sairauden kaltainen ahdistuksen tai lamaantumisen tila. Siinä ollessaan ihminen voi kulkea pitkiä matkoja ja ylittää vaikeakulkuisia maastoja tiedostamatta sitä lainkaan itse. Tilan on joskus kerrottu johtaneen pitkäaikaiseen sairastamiseen tai jopa kuolemaan, mutta vähintään sen jälkitilaksi mainitaan poikkeuksellinen uupumus ja vuorokausia jatkuva unentarve. Paras keino välttyä raimautumiselta on maltin säilyttäminen ja oikeanlainen rituaalinen käyttäytyminen olennon kohtaamistilanteessa. (Pentikäinen 1995, 221-227; Enges 2012, 131-132, 202-206.)

Eksyttäviksi olennoiksi mainitaan eri puolilla Suomea myös piru ja metsänhaltija. Pirun kerrotaan kuljettavan ihmistä nopeaa vauhtia tai lennättävän tätä tuulispäässä, ja lopulta tämä löytyy huonokuntoisena, oudosta paikasta ja kaukana kotoaan (tarinatyypit E 701-800). Pirun kohdalla tapahtuman taustana on usein normirikkomus: kuljetettava on voinut syyllistyä syntiin (E 721) tai joutua muiden kiroamaksi (E 711). Metsänhaltijalla, kuten hiidenväelläkin, on ajateltu olevan ihmissilmälle näkymättömiä, eksyttäviä polkuja. Eksyttävä metsänhaltija tai metsänneito on myös voinut kuljettaa inmistä pirun tavoin (tarinatyypit K 2-5). Sarmelan tulkinnan mukaan eksyttävä metsänhaltija on itse asiassa piru, joka esimerkiksi naisen hahmoisena huumaa ihmisen ja vie hänet mukanaan (Sarmela 2007, 344-346).

Uskomusperinteelle on tyypillistä erilaisten olentojen roolien päällekkäisyys. Vieraiden olentojen luokse joutuminen liittyy tyypillisemmin vuorenpeikkoihin tai maahisiin (tarinatyypit $M$ 31, M 62, M 66, M 321, M 411). Niiden maailma on kuviteltu ihmisasutuksen lähistölle, sen alapuolelle tai asumattomiin erämaihin taikka vaihtoehtoisesti fyysiseen paikkaan sijoittumattomaksi rinnakkaistodellisuudeksi. Sinne joutuneen inmisen on täytynyt olla varuillaan ja esimerkiksi kieltäytyä olentojen tarjoamasta ruoasta ja juomasta, jotta ei joutuisi jäämään niiden luokse ikuisiksi ajoiksi. (Enges 2019, 88-89.)

Eri olentoihin liitetyissä eksymiskuvauksissa on monia yhteisiä ja toistuvia sisällöllisiä piirteitä. Uskomusperinteessä myöskin käsitellään nimenomaan fyysistä eksymistä, jossa kokija ei enää ole selvillä omasta sijainnistaan tai suunnastaan. Fyysiseen eksymiseen kietoutuu kuitenkin usein moraalinen aspekti: tapausta voi edeltää eksyneen oma normirikkomus tai se on seurausta toisten ihmisten häneen kohdistamista ajattelemattomista tai pahantahtoisista toimista. Normirikkomuksen lisääminen kertomukseen yliluonnollisen välikohtauksen perusteluksi on tyypillistä kokemuskertomusten perinteenmukaistumiselle. Moraalinen eksyminen tai eksyttäminen ei kuitenkaan ole fyysisen eksymisen välttämätön edellytys, vaan tapaus voidaan esittää myös epäonniseksi sattumaksi. 


\section{Metsänpeitto}

Käsityksissä metsänpeitosta tulee erityisen selvästi esiin tuonpuoleiseen maailmaan joutuminen ja siteiden katkeaminen ihmisyhteisöön. Metsänpeitto on tunnettu lähes koko Suomen alueella, tosin ennen kaikkea kotieläimen katoamiseen liittyvänä (Sarmela 2007, 342-347, kartat 53 ja 54). Ihmisen joutumisesta metsänpeittoon (tarinatyypit K 201, K 221) tai hiidenkätköön (K 231) on kuitenkin myös runsaasti tietoja. Metsänpeitolla on voitu tarkoittaa monia erilaisia epätavallisen eksymisen muotoja, joita yhdistää tapahtuminen arkielämästä ja arjen yhteisöllisyydestä poikkeavassa kontekstissa (Stark 2006, 357). Tällaisissa kokemuksissa metsä edustaa normaalitodellisuudelle vastakkaista, ajatonta ja unenomaista antimaailmaa (Tarkka 1994, 84).

Metsänpeitossa ihminen joutuu eräänlaiseen maagiseen piiriin, jota hän joutuu kiertämään pääsemättä siitä ulos, tai hän alkaa sulautua metsään ja muuttua sen kaltaiseksi. Metsän vangitsema ihminen on näkymätön etsijöidensä silmissä, ja vaikka hän itse voi nähdä ja kuulla etsijänsä, hän ei pysty kommunikoimaan heidän kanssaan. Joissakin tapauksissa kerrotaan, että eksynyttä ohjaa ja häntä ruokkii jokin ihmis- tai eläinhahmoinen tai hahmoltaan epämääräinen olento. Huomionarvoista on, että vanhassa uskomusperinneaineistossa metsänpeittoon joutunut on lähes poikkeuksetta lapsi, nuori tai nainen, joka harhautuu ollessaan marjanpoiminnassa tai paimentaessaan karjaa. Sen sijaan kertomuksia metsästäjistä tai muuten metsäympäristön hyvin tuntevista miehistä on tuskin lainkaan. (Tarkka 2005, 292-294; Stark 2006, 366-367; Sarmela 2007, 344-345.) Metsänpeittoon joutumista on myös voinut edeltää episodi, jossa yksilön jäsenyys yhteisössä on kyseenalaistettu tai kielletty. Esimerkiksi lasta on voitu moittia tai kirota ja lähettää sen jälkeen metsään paimeneen, ja metsän yksinäisyydessä paha toivotus on sitten käynyt toteen. (Stark 2006, 367-371.) Seuraavassa esimerkissä esiintyy useita yliluonnolliselle eksymiselle tyypillisiä aihelmia:

\footnotetext{
Nuorena ollessani tunsin erään miehen jonka sanottiin eräässä talossa ollessaan käskyläispoikana 13-14 vuoden ikäisenä joutuneen lehmän haku reisullaan mehtän peittoon. Mainitun talon ihmisten kuulin sittemmin asiasta tosissaan kertovan mitä poika oli heille itse olostaan kertonut, että kaksi akkaa tapasivat hänet mehtässä ja pakottivat seuraamaan heitä ja veivät hänet suuren juurineen kaatuneen honkan luokse ja kaivoivat juurten mukana kääntyneeseen multaan kuopan ja käskivät hänen olla siinä ääneti "jos äänen päästät niin sinut tapetaan", ruvaksi toivat hänelle mustikoita ja jonkunlaista ilettävää räkää, ja maalasivat hänen jalkansakin polvia myöten mustikoilla, usein lennättivät häntä ilmassakin niin, että hän näki ja tunsi heinäväen kotitalon niitulla. "Jos huudat niin putoat henketi alas" sanoivat akat. Ja veivät taas samaan paikkaan takasin. Näin hän oli useita päiviä eikä häntä etsiskelyistä huolimatta löydetty ennen kuin pyhänä kirkossa rukoiltiin hänen puolestaan, niin toinen akka sanoi toiselle, jää sinä vahtimaan poikaa, yksi akka tappaa lastaan, minä mänen sitä auttamaan. Mutta silloin poikakin pääsi karkuun ja haku miehet löysivät hänet läheltä kotoa pellon aijan takaa. Ja syynä tähän oli pojan iso isän kirous joten pirut ottivat vijattoman pojan kuletellakseen, tällainen oli vanhain ihmisten uskomus mehtän peittoon joutumisesta. Kertomani tapaus pojasta on tapahtunut Toivakan nykyisessä seurakunnassa vuoden 1870 paikkeilla, aikaa en tarkemmin tiedä. (KOTUS. Toivakka. Anshelm Kuokkanen 8.3.1935.)
}

Uno Holmberg selitti varhaisessa artikkelissaan metsänpeiton tuonpuoleiseksi, ihmisten todellisuudelle vastakkaiseksi vainajien maailmaksi (Holmberg 1923, 53-60). Laura Stark tarkastelee metsän vastakkaisuutta esimodernin yksilökäsityksen kontekstissa. Esimodernissa yhteiskunnassa ihmisyksilö oli tavallaan olemassa vain osana omaa yhteisöään, jossa hänellä oli selkeä sosiaalinen rooli. Metsä taas ymmärrettiin heterotopiaksi, anomaaliseksi ja vaaralliseksi ihmisyhteisön ulkopuoliseksi tilaksi. Stark tulkitsee metsänpeittoa tilana, jossa 
yhteisöstä erilleen joutunut yksilö kadottaa identiteettinsä (minuutensa) ja alkaa sulautua häntä ympäröivään vastamaailmaan. Toisinaan sulautuminen ja kyvyttömyys kommunikaatioon muiden ihmisten kanssa on ollut nähtävissä konkreettisesti fyysisinä muutoksina: metsänpeitosta vapautunut löytyy sammalten peittämänä tai suu ja korvat täynnä sammalta. (Stark 2006, 371-374.)

Metsän käänteisyys suhteessa ihmisten alueeseen ja yhteisöön näkyy muun muassa taikuudessa, jolla peittoon joutunut on voinut vapautua. Eksynyt itse on voinut, kuten hiidenväen ja metsänhaltijankin kohdalla, kääntää kaikki vaatteensa nurin ja pukea ne sellaisina takaisin ylleen, manipuloiden siten kohtaamaansa käänteistodellisuutta. Yhteisö taas on voinut vapauttaa metsän peittoon joutuneen yksilön esimerkiksi soittamalla kirkonkelloja ${ }^{6}$ tai kyvykkään tietäjän avulla. (Holmberg 1923, passim; Jauhiainen 1999, K 201; Stark 2006, 359-360; Sarmela 2007, 345.)

Metsänpeittoperinne on ollut ilmeisen ajankohtaista Suomessa 1800-luvulla ja osittain vielä 1900-luvun alussa. Valtaosa arkistoaineistoista (KOTUS, SKS) on taltioitu 1930-luvulla, jolloin raportoidut tapaukset ajoittuvat yleensä useamman vuosikymmenen taakse. Eksymisen yliluonnollinen tulkintakehys oli tuolloin jo menettänyt merkitystään, ja tapauskuvaukset olivat pikemminkin menneisyyttä koskevaa muistitietoa. Tutkijoiden tulkinnat metsän, yksilön ja yhteisön välisistä suhteista metsänpeittoperinteen merkityksellistäjinä koskevat kansanomaista 1800-luvun ajatusmaailmaa.

\section{Uskomusperinne ja selittävä tiedonintressi}

Nykyaikaiset populaaritkin tulkinnat uskomusilmiöistä kierrättävät tieteellisiä diskursseja, ja siksi on syytä perehtyä tässä niiden tieteelliseen selittämiseen ennen uudempien eksymisaineistojen käsittelyä. Uskomusperinteen käsittely niin tutkimuksessa kuin arkikeskusteluissakin voi edustaa erilaisiin tiedonintresseihin perustuvia näkökulmia. Ihmistieteissä erotellaan usein Jürgen Habermasiin viitaten toisistaan kolme tieteellistä tiedonintressiä: ymmärtävä, selittävä ja kriittinen (ks. esim. Raatikainen 2005; Fingerroos ja Haanpää 2006, 36-38; Taira 2019 , 29). Ymmärtävän tiedonintressin päämääränä on lisätä inhimillistä itseymmärrystä. Sitä edustavat muun muassa edellä esitetyt, metsänpeittoperinteen merkityksiä 1800-luvun uskomusperinteessä koskevat tulkinnat, jotka ohjaavat käsittämään entisaikojen ajattelutapoja. Yleisemmällä tasolla hermeneuttiset ja fenomenologiset lähestymistavat tekevät ymmärrettäviksi inhimillisiä, epätavallisiakin kokemuksia arvottamatta niitä (esim. Honkasalo 2017). Kriittinen tiedonintressi pyrkii vaikuttamaan yhteiskuntaan korjaamalla vääriä tietoja taikka vinoutuneita asenteita ja käytäntöjä. Kriittinen tutkimus on etenkin aiempina vuosisatoina paljastanut yliluonnollisia uskomuksia vääriksi; nyttemmin se voi myös korjata niihin liittyviä ennakkoluuloja. Maallikkodiskursseissa uskomuspohjaisia tulkintoja voidaan hyödyntää yhteiskuntakriittisesti malleina vaihtoehtoisille elämäntavoille. Selittävä tiedonintressi puolestaan etsii tarkastelemilleen ilmiöille konkreettisia tai teknisiä syitä ja seurauksia. Uskontojen ja kansanuskon kohdalla selittävän tiedonintressin myötä etsitään paikallisille ja kulttuurikohtaisille yliluonnollisille kokemuksille ja uskomuksille yleisinhimillistä pohjaa erityisesti kognitiivisten, psykologisten, neurologisten ja fysiologisten selitysten

6

Kirkonkellot ovat kristilliseksi identifioituvan ihmisyhteisön symboli, ja niiden soittaminen on akustista tilan haltuunottoa, joka mitätöi metsän tai muun ei-inhimillisen (= ei-kristillisen) toimijan pyrkimykset. Kirkonkelloista pahoilta olennoilta suojautumisessa ks. esim. Kuuliala 1943, 80-82. 
avulla (esim. Ketola, Pyysiäinen ja Sjöblom 2008, 13, 19-22). Etenkin populaarissa keskustelussa selitykset ovat usein myös medikalisoivia (ks. esim. Koski 2016a).

\section{Yliluonnollisiksi koettujen ilmiöiden tieteellinen selittäminen}

Yliluonnollisten kokemusten selittäminen harhaksi, erehdykseksi tai sairauden aiheuttamaksi yleistyi uuden ajan Euroopassa lääketieteen ja kehittyvien luonnontieteiden piirissä 1600-luvulta lähtien sekä 1800-luvulta lähtien psykologiassa ja psykiatriassa. Osittain kyse on ollut valistushenkisestä ja samalla kriittisestä intressistä, jossa yliluonnollinen kokeminen niin kirkon kuin kansanomaisenkin kokemisen piirissä on pyritty kiistämään tai medikalisoimaan. (Hufford 2005, 21-23; Koski 2016a, 5-7; Pietikäinen 2013, 55, 128-129.) Yliluonnollisten kokemusten ehdoton kiistäminen ja medikalisointi on yleistä nykyään julkisessa ja populaarissa keskustelussa, joissa sitä voi pitää naturalistisen maailmankuvan puolustamisena sitä uhkaavilta ja häiritseviltä selittämättömiltä ilmiöiltä (Koski 2016b, 20-21). Folkloristi David Hufford on nimittänyt tällaista ajattelutapaa epäuskon traditioksi. Hän kritisoi länsimaista tiedettä yliluonnollisiksi tulkittujen kokemusten "pois selittämisestä" ja niiden mitätöimisestä taikauskon tai alentuneen mentaalisen kapasiteetin luomina harhoina. Hänen mukaansa pois selittäminen on korvannut ilmiöiden kunnollisen tutkimisen ja vahvistanut kokijoihin kohdistuvia ennakkoluuloja (Hufford 1982, xiv; Hufford 2005, 13).

Yliluonnollisen selittäminen psykiatrialla tai fysiologialla voidaan nähdä myös ilmiöiden uudelleen nimeämisenä ja toisesta näkökulmasta lähestymisenä ilman erityistä arvottamista (ks. esim. Ross 1996, 4, 11). Lisääntyvää tietoa ihmismielen ja -kehon toiminnasta on hyödynnetty myös sen korostamiseksi, etteivät kaikki epätavalliset kokemukset kieli sairaudesta (esim. Arbman 1963; Korkeila ja Koski 2017). Tästä näkökulmasta katsoen kokemusten yleisinhimillinen psykologinen tai fysiologinen pohja todistaa niiden olevan aitoja ja sellaisina tutkimisen arvoisia, vaikkei tutkija pitäisi pätevänä niiden yliluonnollista selitystä.

Selittävä tutkimusote on perustunut humanistisissakin tieteissä luonnontiedepohjaiseen naturalistiseen maailmankuvaan, jossa ilmiön kansanomaista tulkintaa yliluonnolliseksi tai henkimaailmaan liittyväksi ei pidetä relevanttina. Osa folkloristeista on pitänyt luonnollisten selitysten esittämistä folkloristiikkaan kuulumattomana intressinä, toiset taas ovat hyödyntäneet niitä ja esittäneet kokemusten selitykseksi muun muassa pelkoa ja jännitystä, psykofyysisiä häiriöitä kuten epilepsiaa tai depressiota taikka kokijan intressiassosiaatioita ja perinteen tarjoamaa viitekehystä (ks. Mencej 2018, 52).

Folkloristiikassa yliluonnollisia kokemuksia koskevat tutkimukset pohjautuvat 1900-luvun jälkipuoliskolla alkaneisiin keskusteluihin, joissa hylättiin lopullisesti kokemusten selittäminen tietämättömyydellä tai erehdyksellä. Niitä alettiin lähestyä monitieteisellä ja empiirisellä otteella, ja tunnustettiin kokemuksen realistisuus kokijalle itselleen. Painoarvoa sai myös kokemusten ja niistä kertomisen välinen suhde. (Ward 1977, 212-218, 225.) Tutkijat (esim. Mencej 2018) palaavat edelleen tuolloin käytyihin kiistoihin kulttuurin ja fysiologian roolista. Lauri Honko etsi inkeriläisissä maalaisyhteisöissä koetuille haltijaelämyksille selitystä havaintopsykologian, kokijoiden sosiaalisten roolien ja tradition tuntemuksen pohjalta ja katsoi, että uskomustraditio saa inmiset kokemaan perinteenmukaisia elämyksiä sopivien olosuhteiden vallitessa. Hänen esittämäänsä selitysmallia on nimitetty kulttuurihypoteesiksi. (Honko 1980, 79-88, 90-94; ks. myös Hufford 1982, 12-15.) 
Tutkiessaan 1970-luvulla Newfoundlandin Old Hag -painajaistraditiota David Hufford kritisoi kulttuurihypoteesia kokijoiden toiseuttamisesta taikauskoisiksi. Hänen esittämänsä elämyshypoteesin (experiental source hypothesis) mukaan monet poikkeuksellisina pidetyt elämykset ovat lähtöisin ihmisen fysiologiasta, jolloin ne eivät riipu kulttuurista tai uskomusperinteestä vaan ovat yleisinhimillisiä. Esimerkiksi kokemukset painajaisolennosta perustuvat unihalvauksena tunnettuun fysiologiseen tilaan, johon liittyvät uskomukset vaihtelevat kulttuuritraditiosta toiseen. (Hufford 1982, 15-16, 245-246, 251; ks. myös Davies 2003; de Sá \& Mota-Rolim 2016.)

Hypoteesi fysiologisten tekijöiden ensisijaisuudesta on saanut vahvistusta myös muunlaisten yliluonnollisten elämysten kohdalla ja kansainvälisesti vertailevissa tutkimuksissa (esim. McClenon 2000). Monet fysiologisia selityksiä esittäneet kansanuskon tutkijat muistuttavat kuitenkin, että fysiologinen pohja on vain yksi osa ilmiötä, ja sen lisäksi olennaisia ovat ilmiölle omassa kulttuurissaan annetut sosiaaliset ja kulttuuriset merkitykset. Kun paikallinen uskomustraditio on olemassa, se voi elää kertomuksina ilman kyseisiä kokemuksiakin. Lisäksi kulttuuriset käsitykset ohjaavat myös kokemista kuten yliluonnollisiksi oletettujen kontaktien tavoiteltavuutta tai pelottavuutta. Vaikka Hufford nimesi kulttuuri- ja elämyshypoteesin alkujaan toisilleen vastakkaisina selitystapoina, niiden yhdistäminen tutkimuksessa on osoittautunut hedelmälliseksi. (Enges 2012, 68-69; Mencej 2018; Milne 2019.)

\section{Epätavalliselle eksymiselle annettuja psykologisia ja neurofysiologisia selityksiä}

Epätavallisen eksymisen kuvaukset ovat varsin monimuotoisia jo yksin suomalaisessa uskomusperinteessä, ja variaatio on vielä suurempaa, jos laajennetaan tarkastelua maantieteellisesti ja ajallisesti. Myös ne neuro- ja psykotieteiden määrittelemät tilat, joilla eksymiskokemuksia on selitetty, ovat monimuotoisia. Esimodernien yhteisöjen metsänpeitto, johon joutuivat erityisesti naiset tai lapset, erottuu kansainvälisistä traditioista suomalaiselle perinteelle ominaisena eksymiskokemuksena. Esimerkiksi slovenialaisessa traditiossa painottuvat vastaavasti aikuisia miehiä öiseen aikaan eksyttävät noitaolennot, jotka voivat näkyä valoaistimuksina pimeässä (Mencej 2018, 59, 64). Eroista huolimatta eksymiskokemuksissa toistuvat myös samankaltaiset piirteet, joille voisi etsiä yleisinhimillisiä taustatekijöitä. Suomalaisessa uskomusaineistoissa sellaisia ovat ympäristön muuttuminen vieraaksi ja oudoksi, kokijan lumoutunut tila, jossa hänen kykynsä toimia tai kommunikoida on häiriytynyt, kokemus vieraiden olentojen läsnäolosta ja toisinaan muistikuvien puuttuminen tapahtuneesta jälkikäteen. Folkloristi Mirjam Mencej on esittänyt slovenialaisen aineiston ja myös suomalaiset traditiot huomioivien kansainvälisten vertailujen pohjalta, että uskomustraditioiden eksymiskuvaukset viittaavat autenttisiin kokemuksiin muuntuneista tietoisuuden tiloista ja ovat osapuilleen samankaltaisia kulttuurisista tulkintamalleista riippumatta. Toistuvina piirteinä hän luettelee 1) disorientaation, johon sisältyy myös ympyrän kulkeminen ja ilmassa lennättäminen, 2) kokijan muuntuneen tietoisuuden tilan sekä 3) ajoittain valon tai valojen ${ }^{7}$ näkemisen, joka liittyy mielikuviin eksyttävistä olennoista. Mencej tarkastelee eksymiskokemusten taustalle piirtyvänä muuntuneena tietoisuuden tilana erityisesti ruumiistairtautumiskokemuksia (out-of-body experiences), joihin voi sisältyä tunne lentämisestä, valoista ja niihin liittyvistä olennoista, oudosta liikkeestä sekä paikkaan ja tilaan liittyvien havaintojen muutoksia. (Mencej 2018, 52, 64, 69-76.) 
Suomalaisen uskomusperinteen eksymisaineistot ja etenkin metsänpeittokokemukset muistuttavat enemmän psykologiassa ja psykiatriassa määriteltyä dissosiaatiota. Dissosiaatiolla tarkoitetaan katkoksia yksilön muistin, ajattelun, toiminnan, tunteiden ja identiteetin välisissä, normaalisti saumattomina toimivissa yhteyksissä. Katkosten aiheuttamia oireita ovat muiden muassa oman itsen tunteminen vieraaksi ja epätodelliseksi, tutun ympäristön kokeminen vieraana tai outona, ajan ja paikan tajun kadottaminen, havaintojen vääristyminen ja erilaiset aistihäiriöt. Lievänä ilmenevää dissosiaatiota pidetään normaalina ja varsin yleisenä mielen reaktiotapana, jota voi esiintyä omiin ajatuksiin uppoutuessa, taiteen kokemisen tai mekaanisen suorittamisen yhteydessä. Se yhdistetään myös moniin uskonnollisiin traditioihin, joissa tavoitellaan arjen ylittäviä kokemuksia. Vakavampana se esiintyy voimakkaan stressin ja tunnekokemuksen yhteydessä tai traumaattisten kokemusten jälkeisenä suojamekanismina, jolloin yksilö irrottaa ahdistusta ja kauhua herättävät muistot tai kokemukset tietoisuudestaan luomalla dissosiatiivisen tilan. Dissosiaatiohäiriöihin sisältyy myös niin sanottu pakkovaellus eli dissosiatiivinen fuuga, jossa yksilö pakenee traumaattisesta tai häpeällisestä tilanteesta eikä myöhemmin muista asiaa tai aiempia tapahtumia. (Huttunen 2018; Lauerma 2002, 2199; Ross 1996, 11-14; Rovasalo 2021.) Dissosiaationa voisi siis lähestyä yhtä hyvin monotonisen marjanpoiminnan aiheuttamaa hajamielisyyden tilaa kuin traumaattiselta tilanteelta suojaavaa irtautumista ajasta ja paikasta, jollaiseksi voitaisiin helposti tulkita vanhaan uskomusaineistoon sisältyvät kertomukset haukutun ja kirotun lapsen joutumisesta metsänpeittoon.

Ruumiistairtautumiskokemus ja dissosiaatio ovat psyko- ja neurotieteissä käytettyjä laaja-alaisia termejä kokemustyypeille, joihin liittyy monenlaisia, osittain keskenään päällekkäisiä piirteitä ja joiden asemasta itsenäisinä ilmiöinä esiintyy myös kiistoja. Ruumiistairtautumiskokemuksiin voi katsoa sisältyvän dissosiatiivisia tekijöitä, mutta kumpaankin käsitteeseen liittyy myös paljon muuta. Näin nimettyjen tilojen syntymekanismeiksi on edelleen olemassa joukko vaihtoehtoisia psykologisia, neurologisia ja fysiologisia selitysmalleja. (Braithwaite ym. 2011, 840; Irwin 2000; Lauerma 2002, 2199; Mencej 2018, 69-71.) Epätavallisen eksymiskokemuksen nimeäminen dissosiaatioksi ei siis sinänsä kerro tyhjentävästi, mistä siinä on kysymys. Maallikon tai humanistin tekemänä se on ilmiön siirtämistä psyko-ja neurotieteelliseen diskurssiin, jolla kokemukset ja kokijat integroidaan nykyaikaiseen länsimaiseen todellisuuskuvaan. Humanistisessa tutkimuksessa psykologisten ja fysiologisten selitysten motivaationa on toisaalta elämyshypoteesin viitoittama argumentti: tutkittavana ei ole olematon vaan kokeellisin tietein todennettu ilmiö. Toisaalta nämä diskurssit ovat jo osa myös itse tutkimuskohdetta kuuluessaan outojen kokemusten kuten epätavallisen eksymisen populaariin selitysarsenaaliin. Neuro- ja psykodiskurssit ovat sekä akateemisella että populaarilla kentällä vakiintunut osa epätavallisten kokemusten selittämistä ja tulkintaa.

\section{Nykyaikaisten eksymiskokemusten jäljillä}

Suomalaisen Kirjallisuuden Seura järjesti vuosina 2002-2003 Oletko eksynyt? -keruun (EK), jonka esitteessä (Oletko eksynyt? 2002) vastaajia pyydettiin kirjoittamaan eksymis- ja eksyksistä selviytymisen kokemuksistaan sekä erityisesti näkemyksiään metsänpeitosta ja eksymisen vaaroista. Keruukutsuun vastasi 106 kirjoittajaa ja aineistoa kertyi yhteensä 635 sivua. Vastauksiin sisältyy sekä varsinaisia eksymiskuvauksia ja niiden tulkintoja että ei-kertomusmuotoisia raportteja tai itse eksymisilmiön pohdintaa. Keruukutsun mukaisesti eksyminen on voitu ymmärtää laajasti, sekä luonnon- että kaupunkiympäristössä tapahtuvaksi 
reaaliseksi tapaukseksi, tai metaforisesti, erilaisiin elämäntilanteisiin liittyväksi. (EK; Tolonen 2014, 6, 20-21.)

Toinen nykypäivän ja lähimenneisyyden eksymiskokemuksia valottava aineisto löytyy internetistä keskustelupalstoilta ja blogikirjoitusten kommenttiketjuista. Käytämme Oletko eksynyt? -keruun ohella aineistonamme kolmea viestiketjua, joista vanhin ja pisin on Suomi24-sivustolla vuosina 2006-2018 otsikon 'Oletko kokenut metsänpeiton?' alla käyty keskustelu $(\mathrm{OKM})^{8}$. Keskustelun avaus julkaistiin kesäkuussa 2006:

\begin{abstract}
Vanha kansanperimä tuntee termin 'metsänpeitto'. Joskus esim. sienestäjä voi aivan tutussa metsässä kokea outoja. Häneltä katoavat suuntavaisto ja ajantaju. Metsä alkaa näyttää oudolta. Aika tuntuu seisahtuvan. Jos metsässä on tuulta, ääntä ja liikettä, se kaikki loppuu. Ihminen tuntee vierauden tunnetta eikä hän osaa liikkua paikaltaan tai tuottaa ääntä. Lumoustila katoaa myöhemmin itsestään. Tuon voisi vielä selittää psykologialla. Oudointa kuitenkin on, että jos ihmisellä on metsässä mukanaan tuttuja lähellään, hän ikään kuin katoaa heiltä. He eivät huomaa häntä. Jos kyse on metsään eksyneen joutumisesta metsänpeittoon, hänen etsijänsä eivät löydä häntä, vaikka kulkisivat vierestä. Vanha kansa selitti metsänpeiton sillä, että maahiset ja keijut kostavat ihmiselle sen, että tämä on tullut liian lähelle heidän asuinpaikkaansa. (OKM)
\end{abstract}

Keskustelu on sivustolla sijoitettu alakategoriaan 'Parapsykologia', mikä on todennäköisesti valikoinut kirjoittajia ja vaikuttanut käydyn keskustelun sävyyn. Noin 40 keskustelijasta vain yksi arvioi koko asian pelkäksi hölynpölyksi. Aiheesta eksymiset ja jotkut ironiset ja itseironiset kommentit pois lukien keskusteluketjusta löytyy moniin erilaisiin tulkintakehyksiin pohjautuvia mielipiteitä ja argumentteja. Monet osallistuvat keskusteluun raportoimalla omia tai vanhemmiltaan tai isovanhemmiltaan kuulemiaan tapauksia, toiset taas ottavat asian pohtijan tai selittäjän roolin. Joku on kuullut aikaisemmin metsänpeitto-termin, mutta ei ole tiennyt, mitä se tarkoittaa; toisilla taas on ollut kuvatun kaltaisia kokemuksia, mutta ei niitä luonnehtivaa käsitettä.

Toinen käyttämämme kommenttiketju liittyy blogikirjoitukseen (Leppänen 2012), jonka ensimmäinen kappale on lainattu tämän artikkelin alkuun. Pitkähkössä blogitekstissä pohditaan metsänpeiton olemusta ja viitataan vanhoihin arkistolähteisiin samoin kuin aihepiiriä koskevan tieteellisen tutkimuksen tuloksiin. Blogin kirjoittaja Marko Leppänen esittäytyy Esoteerisen maantieteen koulun perustajana ja muun muassa jungilaiseen syvyyspsykologiaan pohjautuvan periferiaterapian kehittäjänä (Leppänen 2008). Vuosina 2012-2013 syntynyt lyhyt keskusteluketju (kahdeksan kommenttia) kontekstualisoituu luonnontieteeseen pohjautuvalle maantieteelle vaihtoehtoiseen, myös esoteerisen tiedon hyväksyvään näkemykseen ihmisen ympäristö- ja luontosuhteesta.

Kolmas, niin ikään lyhyt keskusteluketju (15 viestiä) julkaistiin Rihmasto - Yhteisöelämän verkosto -sivulla (MPR). Tätä kirjoitettaessa se ei ole enää julkisesti saatavilla. ${ }^{9}$ Keskustelu käynnistyy tiedustelulla: " Osaisiko joku kertoa kauniita asioita metsänpeitosta tai sinne joutumisesta/pääsemisestä." Sitä seuraavassa viestien vaihdossa metsänpeitto määrittyy

8 Vaikka keskustelijoiden nimimerkit ja viestien päivämäärät ovat sivustoilla nähtävissä, viitataan tässä artikkelissa nettikeskusteluihin vain kokonaisuuksina, henkilötietojen minimoinnin periaatetta (Tietosuojavaltuutetun toimisto 2021) noudattaen. Tavoitteena on jäljittää ja määritellä aineistostani erilaisia eksymisen tulkintakehyksiä ja diskursseja, joten yksittäisten kirjoittajien ja kirjoitusten kommentoijien henkilöllisyydellä ei ole analyysin kannalta merkitystä. Ks. myös Suomi24-keskustelupalstaan viittaamisen tapa artikkelissa Johansson ym. 2018.

9 Tällä hetkellä internet-haku johtaa Hipit.fi:n foorumille, joka etusivunsa mukaan on ekologisuudesta, rakkaudesta ja vapaudesta kiinnostuneiden kotifoorumi (Hipit). 
tavoiteltavaksi korkeamman tietoisuuden tilaksi, jota voi myös harjoitella samalla tavoin kuin meditaatiota.

Eri tavoin syntyneet aineistot tarjoavat erilaista tietoa ja tulkintamahdollisuuksia. Internetin keskusteluissa korostuvat - usein spontaanisti, lyhyinä ja kärkevinä kommentteina - erilaiset näkemykset ja niiden välinen jännite. Tutkijoille tai arkistolle kirjoitetut kuvaukset ja pohdinnat sen sijaan ovat syntyneet rauhassa ja ilman pelkoa tylyistä reaktioista. Ne voivat olla avoimempia, syvällisiä ja harkittuja. (Koski-Järvenpää 2017, 272; Koski 2016b, 13-17.) Vastaavasti kun tutkijoille kirjoitetut mietteet voivat olla yksityisiä, uskomusaiheita käsittelevät internet-keskustelut ja niitä ruokkivat blogit ovat kollektiivisempaa ja vuorovaikutuksellisempaa viestintää, jota voi hyvällä syyllä pitää nykyajan uskomusperinteenä: niissä pohditaan outoja ja selittämättömiä ilmiöitä, esitetään kertomuksia ja neuvotellaan tulkinnoista.

Oletko eksynyt? -keruun pohjalta pro gradu -tutkielmansa tehnyt Hanna Tolonen toteaa yleiskuvana aineistosta, että vanhan uskomusperinteen tarjoamaa selkeää eksymisen selitysmallia ei enää löydy, vaan kertomukset kantavat mukanaan hyvin erilaisia kuvauksia ja tulkintoja, joista tyypillisimpiä ovat psykologiset selitykset. Metsänpeitto-käsitettä käytetään edelleen (mahdollisesti siksi, että se esiintyy keruuesitteessä), mutta useimmissa tapauksissa metaforisesti, ilman oletusta ulkopuolisesta yliluonnollisesta aiheuttajasta. (Tolonen 2014, 96.) Keruun aineistoa metsäympäristöön eksymisen osalta analysoinut Seppo Knuuttila on kuitenkin havainnut, että sen kuvaukset noudattavat jokseenkin samanlaisena toistuvaa peruskaavaa:

Suomalaisten nykyiset eksymiskertomukset noudattelevat skriptiä, jonka mukaan aluksi kaikki on
hyvin: metsä on tuttu, se on antelias tai rauhoittava aina sen mukaan, missä tarkoituksessa metsään
on lähdetty. Mutta tilanne vaihtuu äkisti. Kun marjastaja nostaa päänsä, lapsi katsahtaa ympärilleen
tai ajatuksiinsa vaipunut vaeltaja havahtuu, metsä on muuttunut vieraaksi, vaikka se näyttää samalta
kuin äsken. Tuntemattoman koodi syrjäyttää tuttuuden ja ympäristö lähettää uhkaavia viestejä:
mikään ei pidä paikkaansa, entiset ystävälliset puut ovat nyt vihamielisiä, aurinko paistaa väärästä
suunnasta. (Knuuttila 2003,143.)

Keskeinen ero suhteessa vanhaan aineistoon on juuri uskomusolentojen puuttuminen oletettuna eksymisen aiheuttajana, mutta yhteistä vanhojen aineistojen kanssa on eksyneen kyvyttömyys aistia fyysinen ympäristönsä normaalisti ja kommunikoida sen ja muiden ihmisten kanssa. Knuuttila tarkasteleekin keruuaineistoa nimenomaan kommunikaation näkökulmasta. Vanhat aineistot vaikenevat autokommunikaatiosta eli siitä, miten eksynyt neuvottelee itsensä kanssa selvitäkseen tilanteesta; uusissa aineistoissa sen sijaan on kuvauksia kokijan reaktioista, tunteista, ajatuksista ja selviytymiseen tähtäävästä järkeilystä. Nonkommunikaatio taas viittaa ympäristöstä välittyvien tuttujen viestien puuttumiseen ja eksyneen kyvyttömyyteen viestiä muiden ihmisten kanssa: "Metsänpeittokertomusten ydin ja ehto on kommunikaation katkeaminen ulkomaailmaan". (Knuuttila 2003.)

Selkeästi nimettävän ulkopuolisen toimijan sijaan uusissa aineistoissa tapauksen yliluonnollisuus ilmenee usein sen arkijärjen vastaisena "mahdottomuutena". Seuraavassa esimerkissä on kuvattu eksyminen käsittämättömän pienelle alueelle:

Yhdessä toisessa paikassa missä on todella pieni metsä läntti jonne ei kukaan ikinä voisi eksyä, minä kuitenkin kerran eksyin ja ihmettelin miksi metsä vain jatkuu. Oli sellanen hiljasen tuntunen unimainen olo. En tarkkaan muista kuinka kauan eksyminen kesti mutta lopulta pääsin pikku metsä läntiltä 
pois. Kooltaan sellainen suunnilleen noin 10-15 metriä joka suuntiin suunnilleen varmaankin eli tosi pieni saareke. (OKM.)

Koetun ristiriitaisuus kokijan oman todellisuuskäsityksen kanssa keskeinen eksymiskuvauksissa toistuva piirre: koetun kaltaista ei pitäisi tapahtua, mutta oma kokemus todistaa päinvastaista:

[P]idin tätä hölynpölynä, kunnes sattui omalle kohalle. Olin ratsain ja näin ihanan polun tien vieressä. Lähdin seuraamaan sitä, koska etsin uusia maastoreittejä. Metsikkö on sellainen läntti, jota ympäröi muutama talo. Se muodostaa neliön. Toisella puolella tie josta käännyin polulle, sivuilla talot ja päässä taas talo, joskin hieman kauempana. Nooh... siinä sitten ratsastelin ja huomasin että kappas, polku loppuu. Lähdin takaisin päin ja maalainen kun olen, katson aina ympärilleni ja etsin maamerkkejä että osaan VARMASTI suunnistaa takaisin. Ja minulla on hyvä suuntavaisto. Olen penskasta asti metässä liikkunut. Kun käännyin ympäri polkua ei ollut. Siis yksinkertaisesti sitä ei ollut! Tullessani polku ei ollut selvä, mutta painunut selvästikin ja metsän eläimet kulkeneet siitä. Tietysti katselin ympärilleni ja etsin niitä maamerkkejä, mutta tuntui jotenkin tyhmältä. Ei tavallaan nähnyt niitä eikä osannut enää hahmottaa mitään. Niinkuin olisi silmät kiinni pyörinyt ympyrää ja sitten lähtenyt suunnistamaan. Ja omituisinta oli se, että metsässä ei tuullut yhtään eikä missään ollut mitään "elämää". Ei linnut viserrellyt tmv. vaikka lähtiessäni aurinko paistoi ja tuuli mukavasti ja siinä metsässä on todellakin paljon lintuja. Ei auttanut kuin suunnistaa suurin piirtein samaan suuntaan. Tullessani oli kaksi rinnettä mutta palatessani ei ollut kuin yksi. Tuli yhtäkkiä suo, vaikka siinä metsässä El ole soita. Sitten tuli todella tiheä kuusikko, josta oli todella vaikea päästä eteenpäin. Ne oli ilmeisesti joskus siihen istutettu riviin, sillä niiden välissä oli aina ura. Onneksi ratsastin pienellä hepalla, muulla hevosella en olisi päässyt minnekään. Yleensä hevonen osaa kotiin. Mutta tällä kertaa ei. Olin menemässä jo paniikkiin, kunnes lopulta näin punaisen talon ja huomasin olevani naapurin takapihalla. Mutta eihän tällaista voi tapahtua, eihän?? (OKM.)

Teksti sisältää runsaasti yksityiskohtia, joilla kertoja vakuuttelee samanaikaisesti kokemuksensa todenperäisyyttä ja sen poikkeuksellisuutta. Hän painottaa hyvää suuntavaistoaan ja kykyään tehdä jatkuvasti havaintoja maastosta ja painaa mieleensä maamerkkejä. Samoin hän korostaa, että maasto oli hänelle ennestään hyvin tuttu, mutta siitä huolimatta hän joutui eksyksiin. Tilanteen epätavallisuutta korostaa se, että vaikka ihminen voisikin eksyä tutussa maastossa, hevosen ei pitäisi. Kokijaa ympäröivä äkillinen, selittämätön hiljaisuus alleviivaa elämyksen outoutta ja on tärkein todiste sen anomaalisuudesta.

Hetkelliseen eksymiskokemukseen ei välttämättä tarvita edes outoja tai selittämättömiä elementtejä. Seuraavan esimerkin kirjoittaja selittää "lumoutumistaan" marjastuksen monotonisuudella ja poimijan osin tiedostamattomalla ajattelulla:

\footnotetext{
Marjastaminen on minulla varmimpia tapoja lumoutua. Vaikka oikein päättämällä päätän, että nyt pysyn tilanteen tasalla koko poimintajakson, niin eikö vain viimeistään tunnin kuluttua tuo on unohtunut ja olen vajonnut tajunnantilaan, jossa vaihtuvat marjamättäät ja jatkuva, ahkera poiminta ovat jämähtäneet rutiiniksi tajunnanvirraksi. Kun syystä tai toisesta toiminta keskeytyy ja katson ympärilleni, saan hetken ihmetellä mistä olen tähän tullut. "Selviäminen" on tosin ollut melko nopeaa. Näitä lumomaailmaan vaipumisia sattuu minulle lähes joka marjastusreissulla. Syynä lienee se, kun marjastus rutinoituneena ei tarvitse aistien ja rationaalin ajattelun tukea. Mieleen joutaa tulla kaikenlaista metsään(kin) assosioituvaa kulttuuriperinnettä, joka liikkuu päässä itsekseen. Siinä tulee ja menee kertomusten palasia eränkävijöiden kokemuksista, tiedeväen uusista oivalluksista, maailman politiikasta, tarinan pätkiä metsänhaltijoista, Kalevalasta, naapureista, perheestä jne. täyttäen läsnäolon henkisyydellä, mikä stimuloi meitä "löytämään" lisää sitä, mistä kerrottu on. Tätä tukee oivalla tavalla metsäluonnon hiljaisuus. (EK, 235.)
} 
Tässä kirjoituksessa annetaan eksymiselle selitys, joka on nykypäivänä tyypillinen yliluonnollisille tai kummallisille kokemuksille laajemminkin: mitään ulkopuolista aiheuttajaa ei ole, vaan kokemus kumpuaa kokijan omasta psyykestä (Koski-Järvenpää 2017, 281-285). Yliluonnollinen korvautuu tässä selittäjän näkökulmasta rationaalilla psykologisella tulkinnalla, johon hän sisällyttää myös honkolaisen kulttuurihypoteesin sävyä: metsään assosioituva kulttuuriperinne stimuloi kokemaan kerrotun kaltaisia asioita.

\section{Tulkintakehysten kirjo}

Yliluonnollisiksi tai oudoiksi koetuista ilmiöistä käydyissä populaareissa keskusteluissa Suomessa ja muualla länsimaissa erottuu yleensä kolme pääasiallista keskenään kilpailevaa mutta myös toisiinsa sekoittuvaa tulkintakehystä: tieteellinen, kristillinen ja esoteerinen. ${ }^{10}$ Niillä on kullakin hiukan eri tavoin rakentuva auktoriteetti ja toisistaan erottuvat taustaoletuksensa, toimijansa ja sanastonsa. Kaikki keskustelijat eivät kuitenkaan pohjaa näkemyksiään näihin diskursseihin, eivätkä ne ole yhtä toimivia kaikkien outojen kokemusten kohdalla. (Gilhus 2012, 240; Koski 2016b, 12; Koski ja Järvenpää 2017, 272-273; Northcote 2007, 53). Nämä kehykset näkyvät eksymistä ja metsänpeittoa koskevassa kirjoitus- ja internet-aineistossa aihekohtaisin erityispiirtein. Verrattuna muihin yliluonnollista sivuaviin aihepiireihin esimerkiksi kristilliset näkemykset liittyvät eksymiseen vain vähän. Sen sijaan etenkin metsänpeiton kohdalla viitataan vanhaan uskomusperinteeseen paitsi suomalaisten henkisenä kulttuuriperintönä myös omaa tulkintaa ohjaavana mallina.

Eksymisaineistossa naturalistista näkökulmaa edustavat tieteelliset diskurssit muodostavat kiinteän jatkumon arkirealismiin nojaavien näkemysten kanssa, jotka eivät suoraan viittaa tieteeseen mutta edustavat luonnontieteiden legitimoimaa naturalistista ajattelutapaa. Tiedepohjainen argumentointi keskusteluissa edustaa harvemmin varsinaista asiantuntemusta vaan uskoa tieteen auktoriteettiin parhaana maailman selittäjänä (ks. Koski ja Järvenpää 2017, 277-281). Täsmällisemmät argumentit osoittavat, että toisinaan kirjoittajilla ja kommentoijilla on myös syvällisempää aihepiirin tuntemusta. Tieteellisen terminologian ja näkökulmien lähteinä voivat olla oma koulutus, tieteelliset ja populaarit tekstit tai omaan terveydentilaan liittyvät kokemukset. Tiedepohjaisia diskursseja edustavat aineistossa ihmisen anatomiaan ja fyysisiin elintoimintoihin palautuva fysiologinen diskurssi, elämyksiä psyyken ominaisuuksilla perusteleva psykologinen diskurssiin ja niitä patologisoiva sairausdiskurssi. Valtaosa verkkokeskusteluista soveltaa niitä arkisessa muodossa.

Ei sellaista tapahdu. Ei tieteen mukaan. (OKM.)

Sota-aikana silmäilin "Ihmeellinen Suurennuslasi" nimistä kirjaa, siinä selitettiin ihmisen muodostuvan kahdesta puoliskosta. Vasen on selvästi kookkaampi ja siksi vasemmalla jalalla astutaan pitempi askel ja ihminen kaartaa kävellessä oikealle. Kirjassa oli, muistaakseni, väite, että 200x200 metrin suuruisella tasaisella aukiolla kiertää jo kehää. (EK, 157.)

Tietysti myös suggestio ja psykoosi selittävät tälläisiä asioita, samoin kuin väsymys yms... (OKM.)

Huono suuntavaisto ja dementia selittävät tämän hyvin. (OKM.)

Äkillinen verensokerin lasku voi aiheuttaa diabeetikoille noita oireita, sitä vain ei ennenvanhaan tiedetty. (OKM.) 
Uudemmassa aineistossa eksymiskokemusten naturalistisen selitysten kirjo on laaja - kuin päivitetty versio tutkijoiden jo 1700 -luvulla aloittamasta ${ }^{11}$ listauksesta: sumuinen sää, uupumus, humalatila, psyykenlääkkeiden ja huumaavien aineiden käyttö, paniikki, klaustrofobia, suggestio, huono suuntavaisto, diabetes, epilepsia, dementia, mielenterveysongelmat ja dissosiaatio. Kuten seuraava keskustelu dissosiaatiosta osoittaa, psykologiset selitykset eivät ole pelkästään toiseuttavia vaan auttavat kokijoita ymmärtämään hämmentäviä tapahtumia:

Tulkintaehdotus: Olisiko metsänpeiton moderni lääketieteellinen nimitys dissosiaatio? $\rightarrow$ Kom-
mentti 1: Todellakin metsänpeitto näyttäisi muistuttavan monia dissosiaatioilmiöitä tai -oireita.
Ja kuten totesit, tämän termin antaminen ilmiölle ei kuitenkaan mitenkään tyhjennä sitä. $\rightarrow$ Kom-
mentti 2: Dissosiaatiosta tässä taitaa todellakin olla kyse. Itse olen (stressaantuneen ja vaikean tilan-
teen) aikana kokenut metsänpeittoon verrattavan kokemuksen, jonka aikana tunsin eksyväni Helsin-
gin keskustaan, vaikka ympäristö on minulle tuttuakin tutumpi. (MSM.)

Vaikka selityksen etsiminen on ajallemme ominainen intressi, aina erityistä syytä ei kaivata, vaan taipumusta eksymiseen pidetään yksinkertaisesti joillekin yksilöille tyypillisenä piirteenä; kirjoittajien joukossa on "eksymisen mestariksi" ja "ammattilaiseksi" itsensä määritteleviä (esim. EK, 12-14, 95).

Kristillinen tulkintakehys tarjoaa kaksi rinnakkaista, joskaan ei näissä aineistoissa kovin selkeästi ilmaistua näkökantaa. Selittämätön eksyminen ja sen aiheuttajat kielletään kokonaan, koska Jumala ei sallisi sellaisten olemassaoloa, tai se myönnetään todelliseksi, mutta synniksi ja Jumalan tahdon vastaiseksi, ja siksi kaikin mahdollisin keinoin kartettavaksi (OKM.). Kiinnostavasti vanhan uskomusperinteen käsitykset pahantahtoisista ihmisistä eksymisen aiheuttajina liitetään myös kristillisiin tulkintoihin. Noitia ja noituutta tarjotaan keskusteluissa varteenotettavaksi selitysvaihtoehdoksi, mutta eroa löytyy eri tulkintakehyksiin nojautuvien keskustelijoiden asenteissa. Kun kristillisissä tulkinnoissa noituus nähdään yksiselitteisesti vääränä ja syntisenä, uskomusperinteeseen nojaavat tulkitsijat ottavat neutraalimman tai jopa positiivisen kannan; noituutta voidaan pitää arvokkaana osana suomalaista kansanperinnettä. Keskustelun aiheet liikkuvat hyvän- ja pahantahtoisessa noituudessa sekä erilaisten magian asiantuntijoiden (näkijöiden, noitien, šamaanien) rooleissa, ja osa keskustelijoista näyttää suhtautuvan vakavasti mahdollisuuteen, että nykyaikanakin noitia on olemassa ja vahingoittavaa taikuutta harjoitetaan. (OKM, MPR.)

Esoteerinen tulkintakehys sisältää tässä New Agen ja laajan skaalan nykyaikaisia henkisiä suuntauksia, joihin liittyy ajatuksia henkitodellisuudesta, tieteen selityskapasiteetin ylittävistä ilmiöistä ja toimijoista, psyykkisistä voimista ja yksilöllisen henkisen kehityksen tärkeydestä. Myös vanhan uskomusperinteen olentoja voidaan integroida osaksi esoteerista kehystä, yleensä kuitenkin uudelleen tulkittuina. Keskeinen osa länsimaista esoteriaa ovat myös ufot ja avaruusolennot (esim. Partridge 2005, 165-206). Tutkijoiden havainto yhtäläisyyksistä avaruusolentoihin liittyvien kokemuskertomusten ja uskomusperinteen eksytystarinoiden välillä (esim. Bullard 1989, 159; Mencej 2018, 65; Rojcewicz 1991, 491-492) pätee myös suomalaisen metsänpeittoaineiston kohdalla.

11 Esimerkiksi Christfrid Gananderin vuonna 1789 julkaisemassa Mythologia Fennicassa ehdotellaan humalaa, kuumetta ja taikauskoa keijusten näkemisen syyksi (Ganander 1960, 36), ja Martti Haavio listasi haltijanäkyjen mahdollisiksi syiksi humalan, paaston, väsymyksen, kuumeen, raskauden ja imetyksen, pelon, odotuksen ja suggestion (Haavio 1942, 74-78). 
Enivei nyt äkkiseltään tulee mieleeni että joissakin UFOihin liittyneissä tapauksissahan on tainnut olla jotain tämmöistä että yhtäkkiä on kuin toisessa ulottuvuudessa, linnut vaikenevat yms. Muistuttaa mielestäni tätä 'metsänpeittoa' ainakin jossain määrin. (OKM.)

Metsänpeiton nykyinen nimi on Oz-ilmiö, ja se liitetään nimenomaan ufoihin. (OKM.)

Oz-ilmiö (Oz phenomenon, $\mathrm{Oz}$ factor) on brittiläisen ufoaktivistin Jenny Randlesin lanseeraama käsite, joka tarkoittaa avaruusolentojen kanssa lähikontaktiin joutuneen ihmisen muuntunutta tietoisuuden tilaa. Tässä tilassa kokija ei pysty näkemään tai muulla tavoin aistimaan olentojen läsnäoloa, eikä myöskään kuulemaan ääniä tai näkemään muita ihmisiä. Elämystä luonnehtivat äärimmäisen yksinäisyyden ja ajan pysähtymisen tunteet. (Randles 2004.)

Esoteeriseen kehykseen kytkeytyvää omalle todellisuudellemme rinnakkaisten todellisuuksien olemassaoloa ja niihin joutumista tarjotaan myös poikkeuksellisten eksymisten selitykseksi:

\begin{abstract}
Avatkaapaas jo ihmiset silmänne ja huomatkaa että on olemassa myös muita tasoja kuin tämä meidän maanpäällinen tasomme.. "Lintujen laulua" ei kuulunut, koska olitte eri tasolla sillä hetkellä kuin linnut? Tiedä sitten kuinka sinne pääsitte, kaikki on suhteellista.. (OKM.)

Joo, kyseessä voi olla rinnakkastodellisuus siis joku toinen ulotuvuus tai jopa toinen aikakausi jonne jostakin syystä tietyissä olosuhteissa joutuu. Kyllähän rinnakkaistodellisuuksien mahdollisuus on jo teoreettisella tasolla ainakin matemattisesti todistettu kai. (OKM.)
\end{abstract}

Toisiin todellisuuksiin ei kuitenkaan välttämättä jouduta vahingossa. Uushenkisyydessä on keskeistä käsitys ihmisen tietoisuuden eri tasoista ja mahdollisuudesta henkiseen kehitykseen. Yksilöiden, yhteisöjen ja verkostojen edistämä ihmiskunnan henkinen kehitys nähdään toivottavana tai suorastaan elintärkeänä maapallon tulevaisuudelle. (Esim. Lynch 2007, 46-47, 159-160):

Nykyajan erittäin materialistinen elämä on johtanut siihen, että tälläisille ilmiöille ollaan pääsääntöisesti immuuneja. Tämä ei tosin ole ollenkaan hyvä asia, kun ihmisen tietoisuus jää kaikista matalimmalle tasolle. Fyysiselle olemisen tasoalle, josta pitäisi päästä eroon. Ennen ihmiset olivat herkempiä aistimaan energiaa ja luonnon astraaliolentoja/henkiä/otuksia jne eikä tietoisuus ollut niin surullisen rajoittunut. (OKM.)

Vanhassa uskomusperinneaineistossa metsänpeitto ja muut eksymiskokemukset näyttäytyvät vähintään epätoivottuina ja suuressa osassa kertomuksista ne on kuvattu pelottavina ja ahdistavina. 1800-luvun ja 1900-luvun alun suomalaisille metsä on ollut ambivalentti ympäristö: toisaalta arkisiin elinkeinoihin liittyvä mutta toisaalta kodin piiristä poikkeava, pelottavakin tila, jossa normaalit säännöt eivät päde (Harjunen 2019, 53; Tarkka 1994; Virtanen 1994, 136, 138). Uudemmissa aineistoissa pelon ja epätoivon tunteet ovat harvinaisempia, vaikka outous ja selittämättömyys ovat edelleen eksymiskokemusta luonnehtivia piirteitä. Nykypäivän henkisyyden piirissä tilanne voi olla täysin päinvastainen: eksyminen koetaan epätavalliseksi ja erityiseksi, mutta se tulkitaan positiivisesti. Metsä ja sen olennot ymmärretään vanhan perinteen tavoin aktiivisiksi toimijoiksi, mutta ne ovat luonteeltaan ystävällisiä ja suojelevia. Eksymisessä koetaan toteutuvan ihmisen perustavalaatuinen yhteys luontoon:

Metsänpeitto tarkoittaa sitä, että metsä ottaa minut omakseen ja kuljettaa minua sinne, minne toivon tai minne Itseni haluaa minun joutuvan, jotta oppisin jotakin tärkeätä tai löytäisin jotain arvokasta, harvoin tavaraa, useimmiten oivalluksen tai vastauksen suureen ongelmaan. Metsänpeittoon 
pääsemistä auttaa metsän henkien arvostaminen ja ennen kaikkea niihin rakkaudella suhtautuminen. (MPR)

New Age -ajattelussa holistinen todellisuuskuva - kaikki on yhteydessä kaikkeen - ja käsitys ihmisestä osana tuota kokonaisuutta antavat luonnolle erityisen auktoriteettiaseman. Suhteessa tähän ulkopuoliseen auktoriteettiin toimii yksilön sisäinen auktoriteetti, henkinen Itse, joka kehittyy ajan, harjoittelun ja oppimisen myötä. (Heelas 1996, 18-20, 33-35, passim.) Luonnossa yksilö voi tuntea yhteyden kokonaisuuteen ja etsiä opastusta, eikä metsänpeitto henkisyyden tulkintakehyksessä merkitsekään eksyksiin joutumista vaan löytämistä. Tällainen suhtautuminen, jossa metsä hahmotetaan ajattelevana ja tahtovana toimijana, voidaan nähdä osana laajempaa ekospirituaalista liikettä, joka on levinnyt yli koko läntiseen maailman 1960-luvulta lähtien (esim. Partridge 2005, 42-81; Lynch 2007, 35-38, 53-55, 156-157).

Kun on metsänpeitossa, ei koskaan voi eksyä. Metsä ohjaa juuri sinne, minne toivoo. Se tietenkin tuntuu oudolta, että metsän puut eivät enää ole omia tuttuja puita vaan ne näyttäytyvät enemmän psyykkis-henkisinä metsänolentoina, joilla toki on fyysinen olemuksensa, koska niihin saattaa itseään raapaistakin. Tärkeintä on luottamus: sitä saa, mitä tilaa. Metsä pitää aina huolen omistaa aivan kuten Tilassa nimeltä Taivas. (MPR.)

Tämä keskustelija on tarkoituksellisesti kirjoittanut sanan 'Tila' isolla alkukirjaimella; metsänpeitto on hänelle erityinen olemisen Tila, johon rinnastuvia ovat Taivas, Helvetti ja Rakastuminen (MPR.) Uushenkisyyden kontekstissa eksyminen ei ole epämiellyttävää tai pelottavaa, vaan pikemmin tavoiteltava olotila. Metsä näyttäytyy sekä turvallisena piilopaikkana, voiman ja viisauden lähteenä, että aktiivisena toimijana omine tahtoineen ja pyrkimyksineen. Siksi sitä pitää lähestyä kunnioittavasti ja oikein asennoituneena.

\begin{abstract}
Elämyskuvaus: Yritin kerran etsiä mystisiä sieniä, kun metsä eksytti minut. Sisäinen ääni varoitti, että nyt ei ole oikea hetki poimia niitä sieniä, mutta en kuunnellut, vaan jatkoin etsimistä. Kuljin pellonreunaa tutulla seudulla, etsien polun alkua, josta pääsisin tutulle sienipaikalle. Olin kulkenut samaa reittiä usein, eikä polkua voisi olla huomaamatta, kunhan vain seuraisi pellonreunaa. Ajattelin monta kertaa, että seuraavan mutkan jälkeen näen sen polun, mutta lopulta löysin itseni siitä, mistä olin lähtenytkin. Olin kiertänyt koko peltokompleksin ympäri näkemättä polun alkua, vaikka sen olisi pitänyt olla ilmiselvä. Palasin kotiin ilman sieniä. Tuntui, kuin metsä olisi tahallaan kätkenyt polun minulta, koska etsin sieniä väärällä asenteella väärään aikaan. $\rightarrow$ Kommentti: Tuohan on kerrassaan klassinen metsänpeittotapaus: kulkija on tavalla tai toisella väärällä asenteella metsässä ja metsä heittää kapuloita hänen polulleen - tapahtuu outo eksyminen, hetki metsän vankina oloa, ja lopulta nöyrtymisen leimaama paluu ulos. (MSM.)
\end{abstract}

Esoteerisessa tulkintakehyksessä selittävä tiedonintressi väistyy moraaliin ja ihanteisiin liittyvien argumenttien tieltä. Kokemuksista tulee instrumentaalisia ja ne palvelevat henkistä kehitystä ja paremman elämäntavan löytämistä.

Eksymisperinteessä voi nähdä jatkumon varhaismodernista agraarikulttuurista nykypäivän urbanisoituneeseen Suomeen. Kokemusten tulkintakehykset ja niitä ilmentävät diskurssit ovat monipuolistuneet. Kokijat ja keskustelijat hyödyntävät sekä arkikommunikaatiossa välittyviä että tieteellispohjaisia selitysmalleja. Monipuolistumisen myötä myös ehdoton sitoutuminen johonkin niistä näyttää olevan vähäistä; näin on erityisesti internet-keskustelujen kohdalla. Keskusteluihin osallistujat esittelevät outoja, joskus järjenvastaisinakin pitämiään kokemuksia ja yrittävät saada selvyyttä arvoitukselliseen ja mielenrauhaa häiritsevään ilmiöön. Näissä aineistoissa vankin kannatus on tieteelliseen maailmankuvaan 
perustuvilla ja erityisesti psykologisilla selityksillä. Vanhan perinteen kaltaisiin uskomusolentoihin voidaan viitata, tosin vain epämääräisemmin metsän henkinä tai metsän olentoina. Jotkut hyväksyvät ilmiön selittämättömän mystisyyden perustein, jotka ovat tyypillisiä esoteeriselle traditiolle: "On olemassa asioita, joita ei voi selittää lääketieteellä tai psykologialla. Jotkut yrittävät, turhaan. Metsänpeitto on yksi niistä asioista." (OKM.) Ehdottoman varmoja tulkinnoissaan ovat vain ne harvat, jotka mitätöivät asian totaalisesti, kuten Rihmasto-keskustelun päättävä kommentoija: "Voi luoja mitä juttua..." (MPR.)

\section{Metsänpeitto nykyaikaisena metaforana}

Vanhaan uskomusperinteeseen perustuvaa metsänpeiton käsitettä on esitelty tai hyödynnetty 2000-luvulla muun muassa blogikirjoituksissa (esim. Kuvaannollista 2007; TinyBluetits 2019; Esmeraldan eetos 2019), sarjakuvassa ja siihen liittyvässä näyttelyssä (Hukkanen CBF), sanoma- ja aikakauslehtikirjoituksissa (esim. Raatikainen, R. 2015; Tapio 2018), dokumenttielokuvassa (Hämäläinen 2012) ja taideinstallaatiossa (Hanna Tuulikki 2021). Valtaosa näistä esittelee vanhaa uskomusperinnettä ja mahdollisesti liittää siihen omia kokemuksia tai uusia, nykyaikaisia tulkintoja. Metsänpeitto-termille on tullut uusia merkityksiä, jotka palvelevat nykyaikaisia tarpeita: metsänpeitolla tarkoitetaan vetäytymistä metsän suojaan pois nykyajan kiireisestä elämäntavasta. Samalla metsänpeiton uskomusperinteeseen pohjaava tulkinta liukuu henkisestä kohti psykologista ja metaforista. Ajankohtaisten arvojen käsittely ja osoittaminen metaforan ja estetiikan keinoin on vanhallekin uskomusperinteelle ominaista. Metsäsuhdetta ja metsässä kulkemisen meditatiivista vaikutusta käsittelevässä esseessään Vesa Haapala luonnehtii metsänpeiton olemuksellista muutosta seuraavasti:

Kansanperinteessä metsänpeittoa luonnehditaan omituisuuden ja vierauden kokemukseksi. Maailma hiljenee, tuttu vaihtuu nurinkuriseksi. Metsänpeittoon joutunut saattaa jähmettyä liikkumattomaksi tai kulkee oudoksi muuttuneella seudulla. Etsijät eivät löydä kiven tai kannon näköiseksi muuttunutta.

Metsästä vieraantuneen ihmisen kokemus metsänpeitosta on toinen. Metsänpeitto suojaa. Se saa unohtamaan sähkön ja viestinnän. Se antaa hetken rauhan. Metsänpeitto on kokemus itsenäisyydestä, viipymisestä rakennetun ympäristön ulkopuolella. (Haapala 2017.)

Samantyyppistä merkitystä edustaa Mia Jokinivan kehittämään metsäjoogaan liittyvä Metsänpeittoon-meditaatio, jossa hengitetään metsässä ja annetaan "metsän tuoksujen virrata tajuntaa[n]" (Jokiniva 2018). Aktiivisimmillaan 2000-luvun alussa toiminut ekopsykologinen yhdistys Metsänpeitto ry viittaa termillä vastaavasti luonnonläheiseen ja luontoa kunnioittavaan elämäntapaan vastakohtana kulutuskulttuurille (Heiskanen \& Kailo 2006). Taiteilija ja koreografi Hanna Tuulikki kuvaa metsänpeiton käsitteellä nykyaikaisen luontosuhteen traumaattisuutta. Helsinki Biennaalin esittelyssä Metsänpeiton alla -teosta luonnehditaan seuraavasti:

[Metsänpeitto] tarkoittaa eksymistä lumottuun metsään, jossa paikat muuttuvat yhtäkkiä oudoiksi ja kaikki kääntyy ylösalaisin. Perinteisesti metsänpeitto on kuvannut ihmisten katoamista metsään, mutta Hanna Tuulikki tarkastelee sitä nykyaikaisena vertauskuvana emotionaaliselle traumalle, jonka ihminen kokee ympäristötietoisuuden kasvaessa. (Hanna Tuulikki 2021.)

Metsänpeiton ja epätavallisen eksymisen merkitysten laajenemisesta on jonkin verran viitteitä Eksymiskokemukset-kyselyssä (esim. EK, 223-235), joskin keruuesitteen tekstillä on ollut vaikutusta termin käyttöön (Tolonen 2014, 8, 11-12). Tolonen esittää kyselyn aineiston 
pohjalta, että metsänpeitto "tulkitaan pikemminkin poeettisesti ja metaforisesti ilman siihen alun perin liittyvää uskomuspohjaa [--], mutta sen sisältö silti tavoittaa jotain mikä ilmaisee ja välittää taiteellisessa muodossa eksymiseen liittyviä kokemuksia sekä tunteita" (Tolonen 2014, 96). Kyselyssä tiedusteltiin nimenomaan eksymiskokemuksia. Uudessa merkityksessään metsänpeitto ei välttämättä viittaa eksymiseen lainkaan - ellei moraaliseen eksymiseen ja sen sijalle valittuun vaihtoehtoon.

\section{Lisääntyvät selitykset, uudistuvat merkitykset}

Suomalaisissa ja kansainvälisissä tutkimuksissa epätavallista eksymistä ja metsänpeittoa on tarkasteltu sekä ymmärtävän että selittävän tiedonintressin pohjalta, kun taas kriittinen näkökulma toteutuu enemmän maallikkodiskursseissa. Äkillisille ympäristön hahmotuskyvyn ja toimintakyvyn muutoksille on löydetty tutkimuksissa todennäköisiä selityksiä ihmisen psykofyysisistä toimintamekanismeista. Lisäksi tutkijat ovat tarkastelleet ymmärtävästä näkökulmasta niitä ilmiölle annettuja kulttuurisia merkityksiä, jotka heijastavat kertojiensa arvoja ja ajattelutapoja.

Eksymistä ja metsänpeittoa koskevissa populaareissa keskusteluissa, joita voi pitää nykyaikaisena uskomusperinteenä, hyödynnetään sekä ymmärtävän että selittävän tiedonintressin mukaista tietoa. Ensinnäkin ilmiötä taustoitetaan ymmärtävää tiedonintressiä edustavan perinnetieteellisen tiedon avulla. Vanhasta uskomusperinteestä saadaan ilmiölle nimi ja kansanperinteen konteksti, joskus myös aineksia omaan tulkintaan. Toiseksi omien kokemusten ja vanhankin perinteen oikeaksi selitykseksi esitetään psykologian, neurofysiologian ja laajemminkin lääketieteen aloilta löytyvää tietoa. Tieteellisen tai tiedepohjaisen tiedon käyttämisestä outojen ilmiöiden selittämisessä on tullut keskeinen osa nykyaikaista uskomusperinnettä.

Uskomusperinteen strategiana on selittämisen ohella erikoisten ilmiöiden ja kokemusten merkityksellistäminen - niiden kiinnittäminen normeihin, arvoihin ja elämäntarinoihin. Vanhassa uskomusperinteessä yliluonnollisen eksymisen kuvastot heijastivat yksilön ja yhteisön sekä niille vastakkaisen, ihmisen arkiympäristön ulkopuolella levittäytyvän luonnon välistä suhdetta 1800-luvun maalaisyhteisöille ominaisella tavalla, johon liittyivät tuonpuoleiset olennot. Metsänpeitolle 2000-luvulla annettuja arvoladattuja ja kriittisiä merkityksiä hallitsevat uushenkisyys ja ekologia, joissa molemmissa metsänpeitto edustaa myönteistä vetäytymistä hektisestä elämäntyylistä ja suuntautumista kohti metsäluontoa. Uusien tulkintojen rinnalla esitellään yleensä metsänpeiton vanhakin merkitys. Tällainen kehystys paitsi selittää käsitteen alkuperää myös määrittelee metsänpeittoa rajatilaksi, jossa ihmisen ja luonnon välinen suhde on liikkeessä tai ongelmallinen. Se tekee metsänpeiton käsitteestä nykyihmiselle relevantin myös yliluonnolliseen viittaavien diskurssien ulkopuolella.

\section{Tutkimusaineistot}

EK = Eksymiskokemukset-kysely 2003. SKS KRA. Eksymiskokemus. Suomalaisen Kirjallisuuden Seuran arkisto, perinteen ja nykykulttuurin kokoelma, Helsinki.

Esmeraldan eetos 2019: Mystinen metsänpeitto - unohtumaton kokemus. Blogikirjoitus 10.5.2019. Luettu 6.4.2021. https://esmeraldaneetos.blogspot.com/2019/05/mystinenmetsanpeitto-unohtumaton.html. 
Haapala, Vesa 2017: Metsänpeitto. Essee, Yliopistolehti 07/2017. Luettu 13.8.2021.https:// www.helsinki.fi/fi/uutiset/ilmasto-ja-luonnon-monimuotoisuus/metsanpeitto.

Hanna Tuulikki 2021: Metsänpeiton alla. Taideinstallaatio Helsinki Biennaalissa 2021. Luettu 13.8.2021. https://helsinkibiennaali.fi/artist/hanna-tuulikki/.

Hipit: Hipit.fi -foorumi. Luettu 26.4.2021. http://hipit.fi/foorumi/ kommuuni-ekokyla-kamppis-kamppa/rihmasto-yhteisoelaman-verkosto/.

Hukkanen CBF = Hukkanen, Sanna: Metsänpeitto - "Covered by Forest". Luettu 2.4.2021. https://www.sannahukkanen.com/metsanpeitto.

Hämäläinen, Salla 2012: Metsänpeitto / Covered by Forest. Luettu 2.4.2021. https://vimeo. com/82542880.

IMDb. Spirited Away. Luettu 13.8.2021. https://www.imdb.com/title/tt0245429/.

Jokiniva, Mia. 2018. Metsäjooga. Helsinki: Gummerus.

KOTUS $=$ Kotimaisten kielten keskus. Suomen murteiden sana-arkisto. Hakusanat metsänpeitto ja hiidenkätkö.

Kuvaannollista 2007: Metsänpeitto. Blogikirjoitus 27.1.2007. Luettu 13.8.2021. http://kallein. blogspot.com/2007/01/.

Leppänen, Marko 2008: Perusteita: esoteerinen maantiede ja sen sovellus periferiaterapia. Blogikirjoitus 20.8.2008. Luettu 10.4.2021. http://esoteerinenmaantiede.blogspot. com/2008/08/perusteita-esoteerinen-maantiede-ja-sen.html.

Leppänen, Marko 2012: Metsänpeitossa - siis missä? Blogikirjoitus 11.10.2012. Luettu 10.4.2021. http://esoteerinenmaantiede.blogspot.com/2012/10/metsanpeitossa-siismissa.html.

MPR = Metsänpeitto. Rihmasto - yhteisöelämän verkosto. Ei enää julkisesti saatavilla, tallennettu 14.4.2015. http://rihmasto.fi/foorumi/viewtopic.php?t=271.

MSM = Metsänpeitossa - siis missä? Blogikirjoituksen kommenttiketju. Luettu 10.4.2021.

http://esoteerinenmaantiede.blogspot.fi/2012/10/metsanpeitossa-siis-missa.html.

OKM = Oletko kokenut metsänpeiton? Luettu 6.4.2021. https://keskustelu.suomi24. fi/t/3053683/oletko-kokenut-metsanpeiton.

Oletko eksynyt? 2002. Luettu 16.2.2020. http://nebu.finlit.fi/keruuesitteet/eksynyt.pdf.

Raatikainen, Riitta 2015: Metsänpeitossa. Pääkirjoitus \& mielipide. Savon Sanomat 14.7.2015. Luettu 2.4.2021. https://www.savonsanomat.fi/paakirjoitus-mielipide/3104045.

SKS = Suomalaisen Kirjallisuuden Seuran arkisto, perinteen ja nykykulttuurin arkistoaineistot. Uskomustarinat ja memoraatit. Luettu 13.9.2021. https://www.finlit. fi/fi/arkisto/kokoelmat-ja-tiedonlahteet/perinteen-ja-nykykulttuurin-arkistoaineistot/ tekstiaineistot-22\#.YT9kXn2U IU.

Tapio, Jaana 2018: Kun metsä eksyttää. Aarre 7/2018, 42-44.

TinyBluetits 2019: Metsänpeitto. Blogikirjoitus 20.1.2019. Luettu 6.4.2021. https://tinybluetits. blogspot.com/2019/01/metsanpeitto.html.

\section{Kirjallisuus}

Arbman, Ernst. 1963. Ecstacy or Religious Trance in the Experience of the Ecstatics and from the Psychological Point of View. Volume l: Vision and Ecstasy. Uppsala: Svenska Bokförlaget / Nodstedts. 
Braithwaite, Jason, Dana Samson, Ian Apperly, Emma Broglia ja Johan Hulleman. 2010. "Cognitive correlates of the spontaneous out-of-body experience (OBE) in the psychologically normal population: Evidence for an increased role of temporal-lobe instability, body-distortion processing, and impairments in own-body transformations." Cortex 47, 839-853.

Bullard, Thomas. 1989. "UFO Abduction Reports: The Supernatural Kidnap Narrative Returns in Technological Guise." The Journal of American Folklore 102 (404), 147-170.

Davies, Owen. 2003. "The Nightmare Experience, Sleep Paralysis, and Witchcraft Accusations." Folklore 114 (2), 181-203.

Enges, Pasi 2012. "Minämelkein uskon":Yliluonnollinenja sen kohtaaminen tenonsaamelaisessa uskomusperinteessä. Turun yliopiston julkaisuja sarja C, Scripta lingua Fennica edita, osa 338. Turku: Turun yliopisto.

Enges, Pasi. 2019. "Maahiset - melkein kuin ihmiset." Teoksessa Hirvityksiä, haamuja ja henkioppaita: Kirjoituksia uskomusolennoista, toimittaneet Pasi Enges ja Kirsi Hänninen, 74-109. Folkloristiikan julkaisuja 5. Turku:Turun yliopisto.

Etymonline. Luettu 13.8.2021. https://www.etymonline.com/word/spirit.

Fingerroos, Outi ja Riina Haanpää. 2006. "Muistitietotutkimuksen ydinkysymyksiä." Teoksessa Muistitietotutkimus. Metodologisia kysymyksiä, toimittaneet Outi Fingerroos, Riina Haanpää, Anne Heimo ja Ulla-Maija Peltonen, 25-48. Helsinki: Suomalaisen Kirjallisuuden Seura.

Free Dictionary, The. Luettu 13.8.2021.https://idioms.thefreedictionary.com/Spirited+Away.

Ganander, Christfrid. 1960. Mythologia Fennica. 3. painos. Esipuheen kirjoittanut Jouko Hautala. Helsinki: Suomalaisen Kirjallisuuden Seura.

Gilhus, Invild Sælid. 2012. "Angels in Norway: Religious Border-Crossers and Border-Markers." Teoksessa Vernacular Religion in Everyday Life: Expressions of Belief, toimittaneet Marion Bowman ja Ülo Valk, 230-245. Sheffield: Equinox.

Haavio, Martti. 1942. Suomalaiset kodinhaltiat. Porvoo \& Helsinki: Werner Söderström Osakeyhtiö.

Harjunen, Catarina. 2019. “Queer Perspectives on Erotic Human-Supernatural Encounters in Finland-Swedish Folk Legends." Lambda Nordica 1, 46-66.

Heelas, Paul. 1996. The New Age Movement: The Celebration of the Self and the Sacralization of Modernity. Oxford \& Cambridge: Blackwell Publishers.

Heiskanen, Irma ja Kaarina Kailo (toim.). 2006. Ekopsykologia ja perinnetieto. Helsinki: Greenspot,

Holmberg, Uno. 1923. "Metsän peitossa." Kalevalaseuran vuosikirja 3, 16-60. Porvoo: Werner Söderström Osakeyhtiö.

Honkasalo, Marja-Liisa. 2017. "Kirjoituksia elämästä."Teoksessa Mielen rajoilla. Arjen kummat kokemukset, toimittaneet Marja-Liisa Honkasalo ja Kaarina Koski, 11-84. Suomalaisen Kirjallisuuden Seuran Toimituksia 1432. Helsinki: Suomalaisen Kirjallisuuden Seura.

Honkasalo, Marja-Liisa ja Kaarina Koski (toim.). 2017. Mielen rajoilla. Arjen kummat kokemukset. Suomalaisen Kirjallisuuden Seuran Toimituksia 1432. Helsinki: Suomalaisen Kirjallisuuden Seura.

Honko, Lauri. 1980. "Miten luoda terminologia haltiaperinteen tutkimukselle?" Teoksessa Perinteentutkimuksen perusteita, toimittanut Outi Lehtipuro, 77-129. Helsinki: Werner Söderström Osakeyhtiö.

Hufford, David J. 1982. The Terror That Comes in the Night: An Experience-Centered Study of Supernatural Assault Traditions. Publications of the American Folklore Society, New Series, Vol. 7. Philadelphia: University of Pennsylvania Press. 
Hufford, David J. 2005. "Sleep Paralysis as Spiritual Experience." Transcultural Psychiatry 42 (1), 11-45.

Huttunen, Matti. 2018. "Itsensä epätodelliseksi ja vieraaksi tunteminen (depersonalisaatio)." Duodecim terveyskirjasto. Luettu 13.8.2021. https://www.terveyskirjasto.fi/dlk00359.

Irwin, Harvey J. 2000. "The Disembodied Self: An Empirical Study of Dissociation and the Out-Of-Body Experience." The Journal of Parapsychology 64 (3), 261-277.

Jauhiainen, Marjatta. 1999. Suomalaiset uskomustarinat. Tyypit ja motiivit. Tarkistettu ja laajennettu laitos Lauri Simonsuuren teoksesta Typen- und Motivverzeichnis der finnischen mythischen Sagen (FF Communications No. 182. Helsinki 1961). Suomalaisen Kirjallisuuden Seuran Toimituksia 731. Helsinki: Suomalaisen Kirjallisuuden Seura.

Johansson, Marjut, Jarmo Jantunen, Anne Heimo, Mirka Ahonen ja Veronika Laippala. 2018. "Verkkokeskustelujen kansa: Korpusavusteinen diskurssianalyysi Suomi24keskustelupalstasta." Sananjalka 60, 96-117. https://doi.org/10.30673/sja.69963.

Kaivola-Bregenhøj, Annikki. 1988. Kertomus ja kerronta. Suomalaisen Kirjallisuuden Seuran Toimituksia 480. Helsinki: Suomalaisen Kirjallisuuden Seura.

Ketola, Kimmo, Ilkka Pyysiäinen ja Tom Sjöblom. 2008. Uskonto ja ihmismieli. Johdatus kognitiiviseen uskontotieteeseen. Helsinki: Gaudeamus.

Knuuttila, Seppo. 2003. "Eksyminen."Teoksessa Metsään mieleni, toimittaneet Yrjö Sepänmaa, Liisa Heikkilä-Palo ja Virpi Kaukio, 137-149. Helsinki: Maahenki Oy.

Korkeila, Jyrki ja Kaarina Koski. 2017. "Kummat kokemukset, häpeäleima ja psykoosit." Teoksessa Mielen rajoilla: Arjen kummat kokemukset, toimittaneet Marja-Liisa Honkasalo ja Kaarina Koski, 235-267. Helsinki: Suomalaisen Kirjallisuuden Seura.

Koski, Kaarina. 2011. Kuoleman voimat: Kirkonväki suomalaisessa uskomusperinteessä. Suomalaisen Kirjallisuuden SeuranToimituksia 1212. Helsinki:Suomalaisen Kirjallisuuden Seura.

Koski, Kaarina. 2016a. "Yliluonnollista vai patologista?: Kummien kokemusten muuttuvat tulkinnat." Elore vol. 23(1). https://doi.org/10.30666/elore.79241.

Koski, Kaarina 2016b. "Discussing the Supernatural in Contemporary Finland: Discourses, Genres, and Forums." Folklore: Electronic Journal of Folklore 65, 11-36. http://dx.doi. org/10.7592/FEJF2016.65.koski.

Koski, Kaarina ja Marja-Liisa Honkasalo. 2015. "Miten tutkia kummia kokemuksia?" Elore 22 (1), 1-19. https://doi.org/10.30666/elore.79186

Koski, Kaarina ja Juuso Järvenpää. 2017. "Kummien kokemusten tulkinta." Teoksessa Mielen rajoilla: Arjen kummat kokemukset, toimittaneet Marja-Liisa Honkasalo ja Kaarina Koski, 271-301. Suomalaisen Kirjallisuuden Seuran Toimituksia 1432. Helsinki: Suomalaisen Kirjallisuuden Seura.

Kurki, Tuulikki. 2002. Heikki Meriläinen ja keskusteluja kansanperinteestä. Suomalaisen Kirjallisuuden Seuran Toimituksia 880. Helsinki: Suomalaisen Kirjallisuuden Seura.

Kuuliala, Viljo-Kustaa. 1943. Kellot temppelin. Sortavala: Suomen Kirkon Sisälähetysseura.

Lauerma, Hannu. 2002. "Dissosiaatiohäiriöt ja niiden hoito." Duodecim 118 (21): 2199-2205. https://www.duodecimlehti.fi/duo93238.

Lynch, Gordon. 2007. The New Spirituality. An Introduction to Progressive Belief in the Twentyfirst Century. London \& New York: I. B. Tauris.

McClenon, James. 2000. "Content Analysis of an Anomalous Memorate Collection: Testing Hypotheses Regarding Universal Features." Sociology of Religion Vol. 61, No. 2, Summer 2000, 155-169. 
Mencej, Mirjam. 2018. " "Something came over him": Narratives on Being "Carried by Witches" and Their Possible Connection to Altered States of Consciousness." Preternature 7 (1), 50-87.

Milne, Louise. 2019. "One, Two, Many: Dream-Culture, Charms and Nightmares." Teoksessa Charms and Charming: Studies on Magic in Everyday Life, toimittanut Éva Pócs, 129167. Studia Mythologica Slavica, Supplementum 15. Ljubljana: Institute of Slovenian Ethnology.

Northcote, Jeremy. 2007. The Paranormal and the Politics of Truth: A Sociological Account. Exeter: Imprint Academic.

Partridge, Christopher 2005: The Re-Enchantment of the West: Alternative spiritualities, Sacralization, Popular Culture, and Occulture. Volume 2. London \& New York: T \& T Clark International.

Peltonen, Ulla-Maija. 2004. "Kalevalan riemuvuoden kilpakeruu ja hyvän kerääjän käsite." Teoksessa Kansanrunousarkisto, lukijat ja tulkinnat, toimittanut Tuulikki Kurki, 199217. Suomalaisen Kirjallisuuden Seuran Toimituksia 1002. Helsinki: Suomalaisen Kirjallisuuden Seura.

Pentikäinen, Juha. 1995. Saamelaiset:pohjoisen kansan mytologia. Suomalaisen Kirjallisuuden Seuran Toimituksia 596. Helsinki: Suomalaisen Kirjallisuuden Seura.

Pietikäinen, Petteri. 2013. Hulluuden historia. Helsinki: Gaudeamus.

Raatikainen, Panu. 2005. "Ihmistieteet - tiedettä vai tulkintaa?"Teoksessa Ihmistieteet tänään, toimittaneet Anneli Meurman-Solin ja Ilkka Pyysiäinen, 39-61. Helsinki: Gaudeamus.

Rancken, Jeena. 2017. Yliluonnollinen kokemus: Tulkinta, merkitys ja vaikutus. Tampere: Vastapaino.

Randles, Jenny 2004. View from Britain. MUFON UFO Journal, June 2004, 434, 18-19. Luettu 7.4.2021. http://hiddenexperience.blogspot.com/2013/10/the-oz-factor.html.

Rojcewicz, Peter. 1991. "Between one Eye Blink and the Next: Fairies, UFOs, and Problems of Knowledge."Teoksessa The Good People: New Fairylore Essays, toimittanut Peter Narváez, 479-514. New York: Garland Publishing.

Roper, Jonathan. 2018. "Folk Disbelief." Teoksessa Storied and Supernatural Places: Studies in Spatial and Social Dimensions of Folklore and Sagas, toimittaneet Ülo Valk ja Daniel Sävborg, 223-236. Studia Fennica Folkloristica 23. Helsinki: Finnish Literature Society.

Rovasalo, Aki. 2021. “Dissosiaatiohäiriöt." Duodecim terveyskirjasto. Luettu 7.4.2021.

https://www.terveyskirjasto.fi/dlk00360.

Sá, José de \& Mota-Rolim, Sérgio. 2016. "Sleep Paralysis in Brazilian Folklore and Other Cultures: A Brief Review." Frontiers in Psychology 7: 1297.

Sarmela, Matti. 2007. Suomen perinneatlas. Kolmas, osittain uusittu painos. Helsinki: Suomalaisen Kirjallisuuden Seura. https://www.sarmela.net/suomen-perinneatlas/.

Simonsuuri, Lauri. 2006. Kansa tarinoi. Tutkielmia kansantarinoiden salaperäisestä maailmasta. Helsinki: Suomalaisen Kirjallisuuden Seura.

Stark, Laura. 2006. The Magical Self. Body, Society and the Supernatural in Early Modern Rural Finland. Folklore Fellow's Communications 290. Helsinki: Academia Scientiarum Fennica.

SMS 2012: "Hilvata." Suomen murteiden sanakirja. 2012. Kotimaisten kielten keskuksen verkkojulkaisuja 30. Helsinki: Kotimaisten kielten keskus. Jatkuvasti päivitettävä julkaisu. Päivitetty 16.1.2020. Luettu 23.3.2021. http://kaino.kotus.fi/sms.

Taira, Teemu. 2019. Pehmeitä kumouksia. Uskonto, media, nykyaika. Eetos-julkaisuja 17. Turku: Eetos. https://eetos.files.wordpress.com/2019/11/9789527385005-pehmeitakumouksia.pdf. 
Tarkka, Lotte. 1994. "Metsolan merkki: Metsän olento ja kuva vienalaisrunostossa."Teoksessa Metsä ja metsänviljaa, toimittaneet Pekka Laaksonen ja Sirkka-Liisa Mettomäki, 56-102. Kalevalaseuran vuosikirja 73. Helsinki: Suomalaisen Kirjallisuuden Seura.

Tarkka, Lotte. 2005. Rajarahvaan laulu. Tutkimus Vuokkiniemen kalevalamittaisesta runokulttuurista 1821-1921. Suomalaisen Kirjallisuuden Seuran Toimituksia 1033. Helsinki: Suomalaisen Kirjallisuuden Seura.

Tietosuojavaltuutetun toimisto 2021. Tietojen minimointi. Luettu 21.4.2021. https:// tietosuoja.fi/tietojen-minimointi.

Tolonen, Hanna. 2014. Eksymisessä tuntuu että "isopyörä heittää". Käsityksiä ja kokemuksia eksymisestä. Pro gradu -tutkielma. S 665. Helsingin yliopisto. Filosofian, historian, kulttuurin ja taiteiden tutkimuksen laitos / folkloristiikka.

Valk, Ülo. 2015. "Discursive Shifts in Legends from Demonization to Fictionalization."Narrative Culture 2 (1), 141-165.

Virtanen, Leea 1994. "Suomen kansa on aina vihannut metsiään". Teoksessa Metsä ja metsänviljaa, toimittaneet Pekka Laaksonen ja Sirkka-Liisa Mettomäki, 134-140. Kalevalaseuran vuosikirja 73. Helsinki: Suomalaisen Kirjallisuuden Seura.

Ward, Donald. 1977. "The Little Man Who Wasn't There: Encounters With the Supranormal." Fabula 18. Band, 212-225.

Wikman, K. Rob. V. 1961. "Introduction." Teoksessa The Supernatural Owners of Nature. Nordic symposium on the religious conceptions of ruling spirits (genii loci, genii speciei) and allied concepts, toimittanut Åke Hultkrantz, 11-14. Acta Universitatis Stockholmiensis: Stockholm studies in comparative religion 1. Stockholm: Almqvist \& Wiksell.

Wolf-Knuts, Ulrika. 1991. Människan och djävulen. En studie kring form, motiv och funktion $i$ folklig tradition. Åbo: Åbo Akademis förlag.

FT Pasi Enges on folkloristiikan yliopistonlehtori Turun yliopistossa. Hänen erikoisalaansa on suomalainen, saamelainen ja skandinaavinen kansanusko.

FT Kaarina Koski (orcid 0000-0001-6096-8820) on folkloristiikan ja kansanuskontutkimuksen dosentti, joka on erikoistunut kuolemaa ja vainajia, luterilaista kirkkoa ja uskomusolentoja koskeviin uskomustarinoihin sekä nykykulttuuriin. Koski työskentelee Helsingin yliopistossa Suomen Akatemian rahoittamassa "Northern Nightmares 1400-2020"-hankkeessa.

Kirjoittajat kiittävät Eloren toimitusta ja anonyymejä arvioijia arvokkaista kommenteista ja parannusehdotuksista artikkelin viimeistelemiseksi. 